\title{
Metal hydrides: an innovative and challenging conversion reaction anode for lithium-ion batteries
}

\author{
Luc Aymard $^{* 1} 1 \S$, Yassine Oumellal ${ }^{2}$ and Jean-Pierre Bonnet ${ }^{1}$
}

\author{
Review \\ Address: \\ ${ }^{1}$ Laboratoire de Réactivité et Chimie des Solides - LRCS, UMR \\ CNRS-UPJV 7314, 33 rue Saint-Leu, 80039 Amiens, France and \\ 2Institut de Chimie et des Matériaux Paris-Est - ICMPE, UMR \\ CNRS-UPEC 7182, 2-8 Rue Henri Dunant, 94320 Thiais, France

Beilstein J. Nanotechnol. 2015, 6, 1821-1839. doi:10.3762/bjnano.6.186

Received: 10 October 2014

Accepted: 07 August 2015

Published: 31 August 2015

This article is part of the Thematic Series "Materials for sustainable energy production, storage, and conversion".

Guest Editor: M. Fichtner

(c) 2015 Aymard et al; licensee Beilstein-Institut. License and terms: see end of document.

\begin{abstract}
The state of the art of conversion reactions of metal hydrides $(\mathrm{MH})$ with lithium is presented and discussed in this review with regard to the use of these hydrides as anode materials for lithium-ion batteries. A focus on the gravimetric and volumetric storage capacities for different examples from binary, ternary and complex hydrides is presented, with a comparison between thermodynamic prediction and experimental results. $\mathrm{MgH}_{2}$ constitutes one of the most attractive metal hydrides with a reversible capacity of

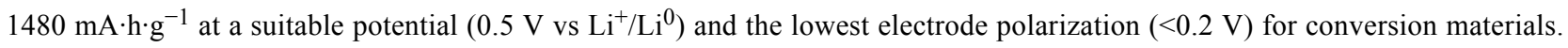
Conversion process reaction mechanisms with lithium are subsequently detailed for $\mathrm{MgH}_{2}, \mathrm{TiH}_{2}$, complex hydrides $\mathrm{Mg}_{2} \mathrm{MH}_{x}$ and other Mg-based hydrides. The reversible conversion reaction mechanism of $\mathrm{MgH}_{2}$, which is lithium-controlled, can be extended to others hydrides as: $\mathrm{MH}_{x}+x \mathrm{Li}^{+}+x \mathrm{e}^{-}$in equilibrium with $\mathrm{M}+x \mathrm{LiH}$. Other reaction paths-involving solid solutions, metastable distorted phases, and phases with low hydrogen content—were recently reported for $\mathrm{TiH}_{2}$ and $\mathrm{Mg}_{2} \mathrm{FeH}_{6}, \mathrm{Mg}_{2} \mathrm{CoH}_{5}$ and $\mathrm{Mg}_{2} \mathrm{NiH}_{4}$. The importance of fundamental aspects to overcome technological difficulties is discussed with a focus on conversion reaction limitations in the case of $\mathrm{MgH}_{2}$. The influence of $\mathrm{MgH}_{2}$ particle size, mechanical grinding, hydrogen sorption cycles, grinding with carbon, reactive milling under hydrogen, and metal and catalyst addition to the $\mathrm{MgH}_{2} /$ carbon composite on kinetics improvement and reversibility is presented. Drastic technological improvement in order to the enhance conversion process efficiencies is needed for practical applications. The main goals are minimizing the impact of electrode volume variation during lithium extraction and overcoming the poor electronic conductivity of $\mathrm{LiH}$. To use polymer binders to improve the cycle life of the hydride-based electrode and to synthesize nanoscale composite hydride can be helpful to address these drawbacks. The development of high-capacity hydride anodes should be inspired by the emergent nano-research prospects which share the knowledge of both hydrogen-storage and lithium-anode communities.
\end{abstract}




\section{Review}

\section{Introduction}

To satisfy the continuously raising need for energy is now a key priority worldwide. The challenge is to obtain environmentally friendly renewable power sources with enhanced electrical energy conversion efficiency at moderate costs. However, these energy sources, such as windmill or solar cells, are intrinsically intermittent and, consequently, need to be associated with efficient energy storage devices in order to provide electricity on demand. With regard to this, lithium-ion (Li-ion) batteries can present an attractive solution, provided that they exhibit sufficient potential and gravimetric/volumetric capacities. Graphite, which is usually used as negative electrode with an intercalation reaction of lithium, is not suitable here due to its intrinsic insufficient specific capacities (370 A $\left.\cdot h \cdot \mathrm{kg}^{-1}, 840 \mathrm{~A} \cdot \mathrm{h} \cdot \mathrm{L}^{-1}\right)$. To overcome these restrictions, new concepts for the negative electrode must be developed, i.e., the Li/graphite intercalation reaction needs to be replaced by either alloying or conversion reactions with lithium. Previously, metal oxides, nitrides, sulfides, phosphides and fluorides were successively investigated as conversion-reaction materials for the negative electrodes of Li-ion batteries [1-4]. In 2008, metal hydrides were proposed for this purpose [5]. Compared to other conversion compounds $\mathrm{MgH}_{2}$ exhibits remarkable properties such as the lowest polarization value for conversion electrodes (less than $0.2 \mathrm{~V}$ ) at an average potential of $0.5 \mathrm{~V}$ vs $\mathrm{Li}^{+} / \mathrm{Li}^{0}$ and a high reversible capacity $\left(1480 \mathrm{~mA} \cdot \mathrm{h} \cdot \mathrm{g}^{-1}\right.$ which is four times that of $\mathrm{Li} / \mathrm{C}$ electrodes). All these properties make $\mathrm{MgH}_{2}$ suitable as a material for negative electrodes. $\mathrm{MgH}_{2}$ reacts with lithium ions in a reversible lithium-driven conversion reaction generating lithium hydride and magnesium metal: $\mathrm{MgH}_{2}+2 \mathrm{Li}^{+}+2 \mathrm{e}^{-} \rightleftharpoons \mathrm{Mg}+$ $2 \mathrm{LiH}$. Moreover, this conversion reaction is not restricted to $\mathrm{MgH}_{2}$. It can also be carried out with several different binary and ternary hydrides. The general chemical reaction is then: $\mathrm{MH}_{x}+x \mathrm{Li}^{+}+x \mathrm{e}^{-} \rightleftharpoons \mathrm{M}+x \mathrm{LiH}$.

The purpose of this review is to describe the properties of these metal hydrides properties in the reaction $\mathrm{vs} \mathrm{Li}^{+} / \mathrm{Li}^{0}$ (conversion reaction) with a focus on thermodynamics, involved reaction mechanisms, and some key issues to improve the performance of hydride-based electrodes.

\section{Conversion reaction of hydrides with lithium ions}

\section{I.1 Gravimetric and volumetric storage capacity of hydrides}

Figure 1 shows both theoretical gravimetric and volumetric capacities of some binary and ternary hydrides. It can be noticed that the capacities of all hydrides are larger than that of graphite (370 A $\left.\cdot h \cdot \mathrm{kg}^{-1}, 840 \mathrm{~A} \cdot \mathrm{h} \cdot \mathrm{L}^{-1}\right)$. Regarding ternary hydrides, the gravimetric capacities are between $340 \mathrm{~A} \cdot \mathrm{h} \cdot \mathrm{kg}^{-1}$
$\left(\mathrm{LaNi}_{4} \mathrm{MnH}_{5}\right)$ and $750 \mathrm{~A} \cdot \mathrm{h} \cdot \mathrm{kg}^{-1}\left(\mathrm{ZrV}_{2} \mathrm{H}_{4.9}\right)$. The highest values are obtained with binary hydrides of light metals, namely $1074 \mathrm{~A} \cdot \mathrm{h} \cdot \mathrm{kg}^{-1}$ and $2038 \mathrm{~A} \cdot \mathrm{h} \cdot \mathrm{kg}^{-1}$ for $\mathrm{TiH}_{2}$ and $\mathrm{MgH}_{2}$, respectively. Volumetric capacities are above $2000 \mathrm{~A} \cdot \mathrm{h} \cdot \mathrm{L}^{-1}$ for all hydrides, for instance, $2298 \mathrm{~A} \cdot \mathrm{h} \cdot \mathrm{L}^{-1}, 2878 \mathrm{~A} \cdot \mathrm{h} \cdot \mathrm{L}^{-1}$, $3815 \mathrm{~A} \cdot \mathrm{h} \cdot \mathrm{L}^{-1}$ for $\mathrm{LaNi}_{4} \mathrm{MnH}_{5}, \mathrm{MgH}_{2}$ and $\mathrm{TiH}_{2}$, respectively. Complex hydrides based on $\mathrm{Mg}$ follow this general trend of hydrides (i.e., capacities larger than graphite with $\mathrm{Mg}_{2} \mathrm{NiH}_{4}$ : $963 \mathrm{~A} \cdot \mathrm{h} \cdot \mathrm{kg}^{-1}, 2822 \mathrm{~A} \cdot \mathrm{h} \cdot \mathrm{L}^{-1} ; \mathrm{Mg}_{2} \mathrm{CoH}_{5}: 1191 \mathrm{~A} \cdot \mathrm{h} \cdot \mathrm{kg}^{-1}$, $\left.3200 \mathrm{~A} \cdot \mathrm{h} \cdot \mathrm{L}^{-1} ; \mathrm{Mg}_{2} \mathrm{FeH}_{6}: 1456 \mathrm{~A} \cdot \mathrm{h} \cdot \mathrm{kg}^{-1}, 3995 \mathrm{~A} \cdot \mathrm{h} \cdot \mathrm{L}^{-1}\right)$. These large capacities render hydrides as good candidate material for negative electrodes in lithium-ion batteries for stationary as well as mobile applications for which the volumetric capacity plays a key role.

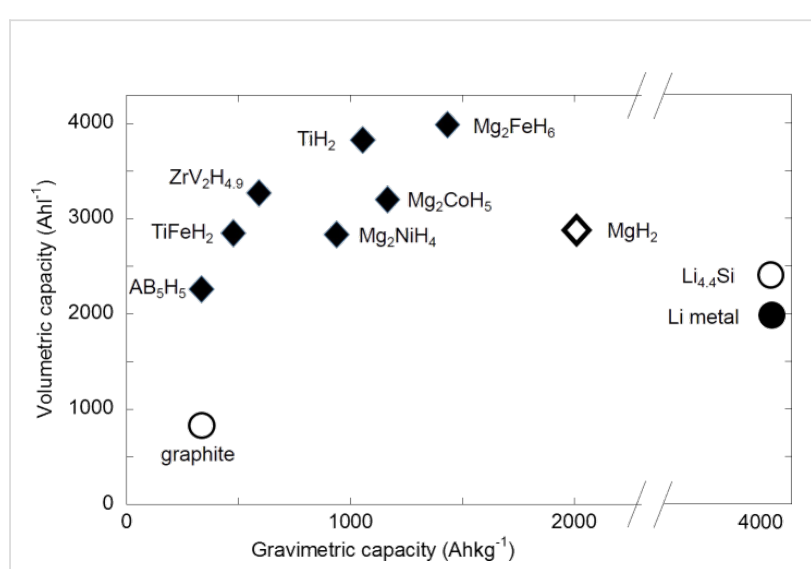

Figure 1: Gravimetric and theoretical volumetric capacities of metals and complex hydrides compared with those of graphite and other materials for negative electrodes. Reproduced with permission from [13]. Copyright 2013 Elsevier.

\section{I.2 Thermodynamics of hydrides}

After experimental results on the conversion reaction with $\mathrm{MgH}_{2} / \mathrm{Li}[5,6]$ were reported, other systems that could be involved in the electrochemical conversion process were addressed from thermodynamic rules. The general reaction between hydride and lithium is given in Equation 3, where $\mathrm{MH}_{x}$ is the hydride, $\mathrm{M}$ the metal or the intermetallic phase, and $x$ the number of hydrogen atoms. Under standard conditions ( $p=1$ atm and $T=298 \mathrm{~K}$ ), the Gibbs free energy of the reaction in Equation $3, \Delta_{\mathrm{r}} G$ in $\mathrm{kJ} \cdot \mathrm{mol}^{-1}$, can be calculated from the values of Gibbs free energy of formation of $\mathrm{MH}_{x}$ and $\mathrm{LiH}$ $\left(\Delta_{\mathrm{f}} G^{\circ}{ }_{298}(\mathrm{LiH})\right.$ and $\Delta_{\mathrm{f}} G^{\circ}{ }_{298}\left(\mathrm{MH}_{x}\right)$. It corresponds to the sum of reactions (Equation $1+$ Equation 2) given as:

$$
x\left(\mathrm{Li}+1 / 2 \mathrm{H}_{2} \rightarrow \mathrm{LiH}\right) ; \quad x \Delta_{\mathrm{f}} G_{298}^{\circ}(\mathrm{LiH})
$$




$$
\begin{gathered}
\mathrm{MH}_{x} \rightarrow \mathrm{M}+x / 2 \mathrm{H}_{2} ;-\Delta_{\mathrm{f}} G^{\circ}{ }_{298}\left(\mathrm{MH}_{x}\right), \\
\mathrm{MH}_{x}+x \mathrm{Li} \rightarrow \mathrm{M}+x \mathrm{LiH} ; \quad \Delta_{\mathrm{r}} G_{298}^{\circ} .
\end{gathered}
$$

The Gibbs free energy of the reaction in Equation 3 is:

$$
\begin{aligned}
\Delta_{\mathrm{r}} G_{298}^{\circ}= & {\left[\Delta_{\mathrm{f}} G^{\circ}{ }_{298}(\mathrm{M})+x \Delta_{\mathrm{f}} G^{\circ}{ }_{298}(\mathrm{LiH})\right] } \\
& -\left[\Delta_{\mathrm{f}} G^{\circ}{ }_{298}\left(\mathrm{MH}_{x}\right)+x \Delta_{\mathrm{f}} G^{\circ}{ }_{298}(\mathrm{Li})\right] \\
\Delta_{\mathrm{r}} G_{298}= & \Delta_{\mathrm{r}} G^{\circ}{ }_{298} \\
= & x \Delta_{\mathrm{f}} G^{\circ}{ }_{298}(\mathrm{LiH})-\Delta_{\mathrm{f}} G^{\circ}{ }_{298}\left(\mathrm{MH}_{x}\right) .
\end{aligned}
$$

According to the thermodynamics rules, the reaction is feasible for $\Delta_{\mathrm{r}} G^{\circ}{ }_{298} \leq 0$ and spontaneous for $\Delta_{\mathrm{r}} G^{\circ}{ }_{298}<0$.

Given the fact that the formation of $\mathrm{LiH}$ independent from the type of hydride $\mathrm{MH}_{x}$ (common reaction product), another simple criterion to predict the possibility of the conversion process is the Gibbs free energy of formation of the hydride $\mathrm{MH}_{x}$ divided by $x$. This value must be above that of $\mathrm{LiH}$ $\left(\Delta_{\mathrm{f}} G^{\circ}{ }_{298}\left(\mathrm{MH}_{x}\right) / x>\Delta_{\mathrm{f}} G^{\circ}{ }_{298}(\mathrm{LiH})\right)$. The knowledge of reaction Gibbs free energy allows for the evaluation of the electromotive force (emf) and of the equilibrium potential of the cell, $E$, by using the Nernst law: $\Delta_{\mathrm{r}} G^{\circ}=-x \cdot E \cdot F$ ( $F$ : Faraday constant, $x$ : number of electrons involved in the reaction). The equilibrium potential of the cell is deduced from the half reaction (Equation 4 and Equation 5) and the sum reaction (Equation 6).

$$
\begin{gathered}
\mathrm{MH}_{x}+x \mathrm{Li}^{+}+x e^{-} \rightarrow \mathrm{M}^{0}+x \mathrm{LiH} ; \Delta G_{\mathrm{I}, 298}^{\circ} \\
x \mathrm{Li}^{0} \rightarrow x e^{-}+x \mathrm{Li}^{+} ; \Delta G^{\circ}{ }_{\mathrm{II}, 298}
\end{gathered}
$$

$$
\mathrm{MH}_{x}+x \mathrm{Li}^{+} \rightarrow \mathrm{M}^{0}+x \mathrm{LiH} ; \quad \Delta G^{\circ}{ }_{\mathrm{III}, 298} .
$$

Hess's law gives:

$$
\begin{aligned}
& \Delta G_{\mathrm{III}, 298}^{\circ}=\Delta G_{\mathrm{I}, 298}^{\circ}+\Delta G^{\circ} \mathrm{II}, 298, \\
& \Delta G_{\mathrm{I}, 298}^{\circ}=-x E_{0}^{\circ}\left(\mathrm{MH}_{x} / \mathrm{M}^{0}, \mathrm{LiH}\right) F, \\
& \Delta G_{\mathrm{II}, 298}^{\circ}=-x E_{0}^{\circ}\left(\mathrm{Li}^{+} / \mathrm{Li}^{0}\right) F=0, \\
& \quad \text { the couple }\left(\mathrm{Li}^{+} / \mathrm{Li}^{0}\right) \text { being used as reference, } \\
& \Delta G_{\mathrm{III}, 298}^{\circ}=\Delta G_{\mathrm{I}, 298}^{\circ}=\Delta_{\mathrm{r}} G_{298}^{\circ}, \\
& \Delta_{\mathrm{r}} G_{298}^{\circ}=-x E F=-x E_{0}^{\circ}\left(\mathrm{MH}_{x} / \mathrm{M}^{0}, \mathrm{LiH}\right) F, \\
& E_{0}^{\circ}\left(\mathrm{MH}_{x} / \mathrm{M}^{0}, \mathrm{LiH}\right) F=-\Delta_{\mathrm{r}} G_{298}^{\circ} / x F .
\end{aligned}
$$

With a lithium activity $a(\mathrm{Li})=0$, and a lithium ion concentration $\left[\mathrm{Li}^{+}\right]=1 \mathrm{M}\left(\left[\mathrm{Li}^{+}\right]\right.$inside the electrolyte), the equilibrium potential of the cell $\left(E_{\mathrm{eq}}\right)$ is:

$$
\begin{aligned}
& E_{\text {eq }}\left(\mathrm{MH}_{x} / \mathrm{M}^{0}, \mathrm{LiH}\right)=E_{0}^{\circ}\left(\mathrm{MH}_{x} / \mathrm{M}^{0}, \mathrm{LiH}\right) \\
& E_{\text {eq }}\left(\mathrm{MH}_{x} / \mathrm{M}^{0}, \mathrm{LiH}\right)=-\Delta_{\mathrm{r}} G_{298}^{\circ} / x F .
\end{aligned}
$$

This calculation was applied for different binary and ternary hydrides used to represent the different intermetallic families. The HSC database [7] and literature data [8] were used to obtain the $\Delta_{\mathrm{f}} H, \Delta_{\mathrm{f}} G$ and $\Delta_{\mathrm{f}} S$ values.

I.2.1 Binary hydrides: Figure 2a shows the equilibrium potential of the $\mathrm{MH}_{x} / \mathrm{Li}$ cell for different binary hydrides $\mathrm{M}=\mathrm{Y}, \mathrm{La}$, $\mathrm{Ba}, \mathrm{Ca}, \mathrm{Zr}$, Ti, Na, Cs, Mg. The potential versus $\mathrm{Li}^{+} / \mathrm{Li}^{0}$ is positive for $\mathrm{Zr}, \mathrm{Ti}, \mathrm{Na}, \mathrm{Cs}$ and $\mathrm{Mg}$ and negative for $\mathrm{Y}, \mathrm{La}, \mathrm{Ba}$ and $\mathrm{Ca}$ hydrides. It can be clearly concluded from this figure that the conversion reaction is favorable, from a thermodynamics point of view, for $\mathrm{Zr}$, Ti, $\mathrm{Na}, \mathrm{Cs}$ and $\mathrm{Mg}$ hydrides and not possible for Y, La, Ba, Ca. The Gibbs free enthalpy of forma-

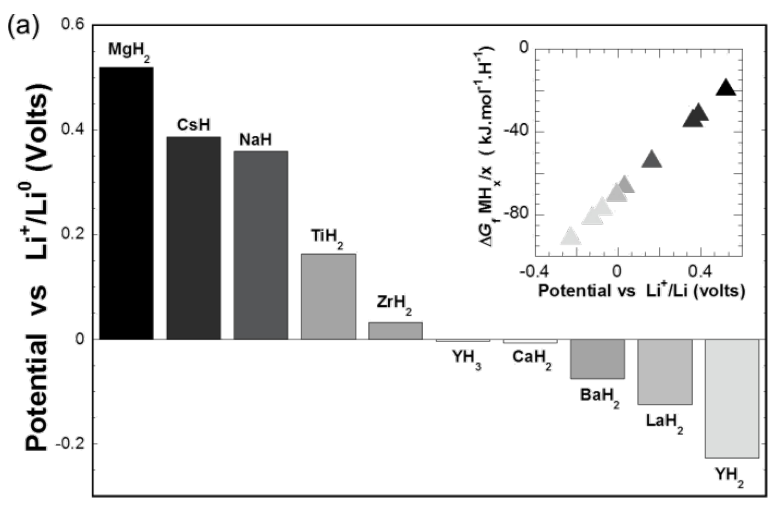

Binary hydrides

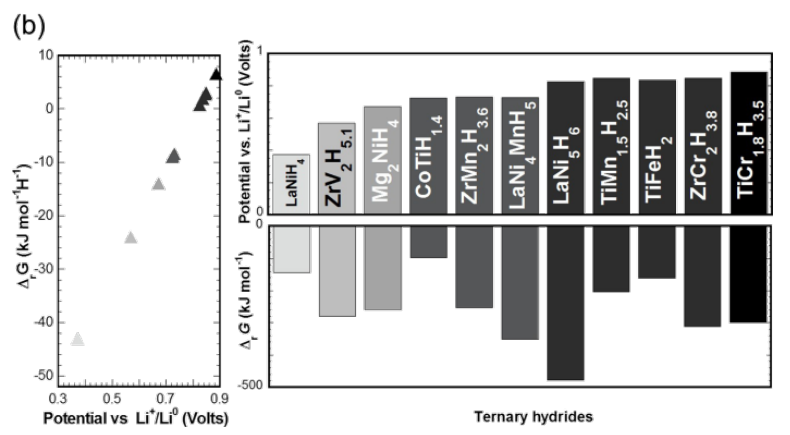

Figure 2: Theoretical equilibrium potential for the $\mathrm{MH}_{x} / \mathrm{Li}$ cell vs $\mathrm{Li}^{+} / \mathrm{Li}^{0}$ a) For binary hydrides $\mathrm{M}=\mathrm{Y}, \mathrm{La}, \mathrm{Ba}, \mathrm{Ca}, \mathrm{Zr}, \mathrm{Ti}, \mathrm{Na}, \mathrm{Cs}, \mathrm{Mg}$. Inset: Gibbs free formation enthalpy of these hydrides as a function of the equilibrium potential. b) For ternary hydrides $\mathrm{Mg}_{2} \mathrm{NiH}_{4}, \mathrm{LaNiH}_{4}$, $\mathrm{CoTiH}_{1.4}, \mathrm{TiFeH}_{2}, \mathrm{ZrV}_{2} \mathrm{H}_{5.1}, \mathrm{ZrCr}_{2} \mathrm{H}_{3.8}, \mathrm{ZrMn}_{2} \mathrm{H}_{3.6}, \mathrm{TiMn}_{1.5} \mathrm{H}_{2.5}$, $\mathrm{TiCr}_{1.8} \mathrm{H}_{3.5}$, $\mathrm{LaNi}_{5} \mathrm{H}_{6}$, $\mathrm{LaNi}_{4} \mathrm{MnH}_{5}$ [11]. 
tion (divided by the amount of substance of hydrogen) of these hydrides is smaller than that of $\mathrm{LiH}$ (inset Figure 2a).

I.2.2 Ternary hydrides: In the case of ternary hydrides, equilibrium potentials of the $\mathrm{MH}_{x} / \mathrm{Li}$ cells were evaluated for different representative compounds $\mathrm{AB}_{x}$ of intermetallic families (with $x=0.5,1,2$ and 5) and their corresponding hydrides $\left(\mathrm{Mg}_{2} \mathrm{NiH}_{4}, \mathrm{LaNiH}_{4}, \mathrm{CoTiH}_{1.4}, \mathrm{TiFeH}_{2}, \mathrm{ZrV}_{2} \mathrm{H}_{5.1}, \mathrm{ZrCr}_{2} \mathrm{H}_{3.8}\right.$, $\mathrm{ZrMn}_{2} \mathrm{H}_{3.6}, \mathrm{TiMn}_{1.5} \mathrm{H}_{2.5}, \mathrm{TiCr}_{1.8} \mathrm{H}_{3.5}, \mathrm{LaNi}_{5} \mathrm{H}_{6}, \mathrm{LaNi}_{4} \mathrm{MnH}_{5}$ ). Figure $2 \mathrm{~b}$ (lower part) shows that the Gibbs free enthalpy of formation value for all these ternary hydrides (per mole hydrogen) is above that of LiH. For these hydrides the equilibrium potential of the cell is positive (Figure $2 b$ ) and the conversion reaction can be achieved. Equilibrium potentials are in the range of $0.3-1.0 \mathrm{~V} \mathrm{vs} \mathrm{Li}^{+} / \mathrm{Li}^{0}$, which is suitable for a negative electrode in Li-ion batteries. The equilibrium potential of the cell can be adjusted for different $\mathrm{AB}_{x}$ intermetallic families by varying the site substitutions of $A$ and $B$ [8]. In fact, the plateau pressure of hydride correlates with the lattice cell volume, allows one to change the thermodynamic stability of the hydrides, especially for the families $\mathrm{AB}_{5}$ and $\mathrm{AB}_{2}$. Depending of the nature of the hydrides a wide range of hydrogen sorption temperatures from -40 to $300{ }^{\circ} \mathrm{C}$ gives another argument to a tailor a negative electrode for the desired applications [9].

\section{I.3 Comparison between thermodynamic prediction and experience}

Figure 3 shows the experimentally measured potential vs $\mathrm{Li}^{+} / \mathrm{Li}^{0}$ for electrochemical $\mathrm{MH}_{x} / \mathrm{Li}$ cells using binary and ternary hydrides. The potential-capacity curves recorded are in agreement with the assumption based on thermodynamics that the conversion reaction is possible for $\mathrm{MgH}_{2}, \mathrm{TiH}_{2}, \mathrm{NaH}$ and ternary hydrides. These discharge curves correspond to the theoretical reaction $\mathrm{MH}_{x}+x \mathrm{Li}^{+}+x \mathrm{e}^{-} \rightarrow \mathrm{M}^{0}+x \mathrm{LiH}$ and their lengths are in agreement with the number of hydrogen atoms that react with lithium (Figure 3a). For instance the discharge curves of $\mathrm{MgH}_{2}, \mathrm{TiH}_{2}$ [10], $\mathrm{NaH}$ involve two and one lithium respectively for two and one hydrogen [11]. Values superior to the number of hydrogen atoms $x$ can, however, be reached in relation with either a plateau corresponding to the electrolyte decomposition on carbon at $0.8 \mathrm{~V}$ or with a metal alloying reaction at low potentials, especially for $\mathrm{Mg}\left(0.17 \mathrm{~V} \mathrm{vs} \mathrm{Li}^{+} / \mathrm{Li}^{0}\right)$. The potential-capacities curves are lower than the theoretical equilibrium potential due to internal resistance of the cell and are also not totally flat due to kinetic limitations of the system. The equilibrium potential of the $\mathrm{MH}_{x} / \mathrm{Li}$ cells can be obtained by galvanostatic intermittent titration (GITT) in open circuit voltage with, for instance, an experimental value of $0.537 \mathrm{~V}$ for the $\mathrm{MgH}_{2} / \mathrm{Li}$ cell [11], which is in good agreement with the theoretical value of $0.560 \mathrm{~V}$ versus $\mathrm{Li}^{+} / \mathrm{Li}^{0}$ obtained from Nernst law.
Regarding $\mathrm{AB}_{x}$ intermetallic compounds, typical discharge curves obtained from ternary hydrides $\mathrm{LaNi}_{4} \mathrm{MnH}_{5}$, TiNiH [12], bcc $\mathrm{Ti}_{0.20} \mathrm{~V}_{0.78} \mathrm{Fe}_{0.02} \mathrm{H}_{1.55}$ and $\mathrm{Mg}_{0.65} \mathrm{Sc}_{0.35} \mathrm{H}_{2.25}$ are presented in Figure $3 \mathrm{~b}$. Lengths of discharge curves of $x=4.8,1.2,1.3$, and 2.2 are recorded for $\mathrm{LaNi}_{4} \mathrm{MnH}_{5}, \mathrm{TiNiH}$, bcc $\mathrm{Ti}_{0.20} \mathrm{~V}_{0.78} \mathrm{Fe}_{0.02} \mathrm{H}_{1.55}$ and $\mathrm{Mg}_{0.65} \mathrm{Sc}_{0.35} \mathrm{H}_{2.25}$ hydrides, respectively. It must be noted that a nice flat plateau is obtained for the $\mathrm{AB}_{5}$ compound.

Conversion reactions with lithium ions were also carried out with different complex hydrides based on $\mathrm{Mg}$ or $\mathrm{Al}$, especially $\mathrm{Mg}_{2} \mathrm{FeH}_{6}, \mathrm{Mg}_{2} \mathrm{CoH}_{5}$ and $\mathrm{Mg}_{2} \mathrm{NiH}_{4}$. These complex hydrides were prepared by reactive grinding $[13,14]$. They react with lithium ions at average potentials of $0.25,0.24$ and $0.27 \mathrm{~V}$ and give discharge capacities of $6.6,5.5$ and $3.6 \mathrm{Li}$, respectively. Using $\mathrm{AlH}_{3}$ [15], $\mathrm{Li}_{3} \mathrm{AlH}_{6}$ [16] or more recently $\mathrm{LiAlH}_{4}$, $\mathrm{NaAlH}_{4}$ and $\mathrm{Na}_{3} \mathrm{AlH}_{6}[17,18]$ as negative electrode of Li-ion batteries was also reported. It demonstrates the possibility to extend the conversion process to numerous versatile complex hydrides. For these last cases, the discharge curves involve conversion process and alloying reaction, in relation to the close potential of both reaction types.

\section{Conversion process reaction mechanisms for hydrides}

Reactivity of hydrides with lithium ions predicted from thermodynamic rules and experimentally confirmed for different hydrides is assumed to be a conversion reaction as $\mathrm{MH}_{x}+x \mathrm{Li} \rightarrow \mathrm{M}+x \mathrm{LiH}$. While this general mechanism is obvious, more complex reactions path involving the formation of alloys, solid solutions, metastable or amorphous phases can also be noticed. In the following paragraph reaction mechanisms occurring with $\mathrm{MgH}_{2}[5,11], \mathrm{TiH}_{2}$ [10], $\mathrm{Mg}_{0.85} \mathrm{Sc}_{0.65} \mathrm{H}_{2}$ and $\mathrm{Mg}_{2} \mathrm{TMH}_{x}(\mathrm{TM}=\mathrm{Fe}, \mathrm{Co}, \mathrm{Ni}, x=6,5,4)[14]$ hydrides will be described.

\section{II.1 Reaction of $\mathrm{MgH}_{2}$ with lithium}

The reaction of $\mathrm{Mg}$ hydride with lithium ions is the first example reported in the literature of a Li-driven conversion reaction with hydrides [5,11]. The electrochemical curve recorded at a low cycling rate (one equivalent of lithium in $100 \mathrm{~h}$ ) during the reaction of $\mathrm{MgH}_{2}$ with $\mathrm{Li}$ (inset of Figure 4a) shows that the full discharge (length $x=2.5 \mathrm{Li}$ ) involves two plateaus at $0.44 \mathrm{~V}$ and $0.095 \mathrm{~V}$. The XRD patterns, collected at different discharge steps, are presented in Figure 4a. The XRD patterns corresponding to the first plateau (until $x=1.8 \mathrm{Li}$ ) show a decrease of the intensity of $\mathrm{MgH}_{2}$ (tetragonal and orthorhombic phases) Bragg peaks and the appearance of hcp $\mathrm{Mg}$ and bcc Li peaks $((100,002,101)$ and $(111,200)$, respectively). Above $x=1.8$ (Figure 4b) the first slope observed in the discharge curve corresponds to a shift of the Mg XRD lines in 
(a)
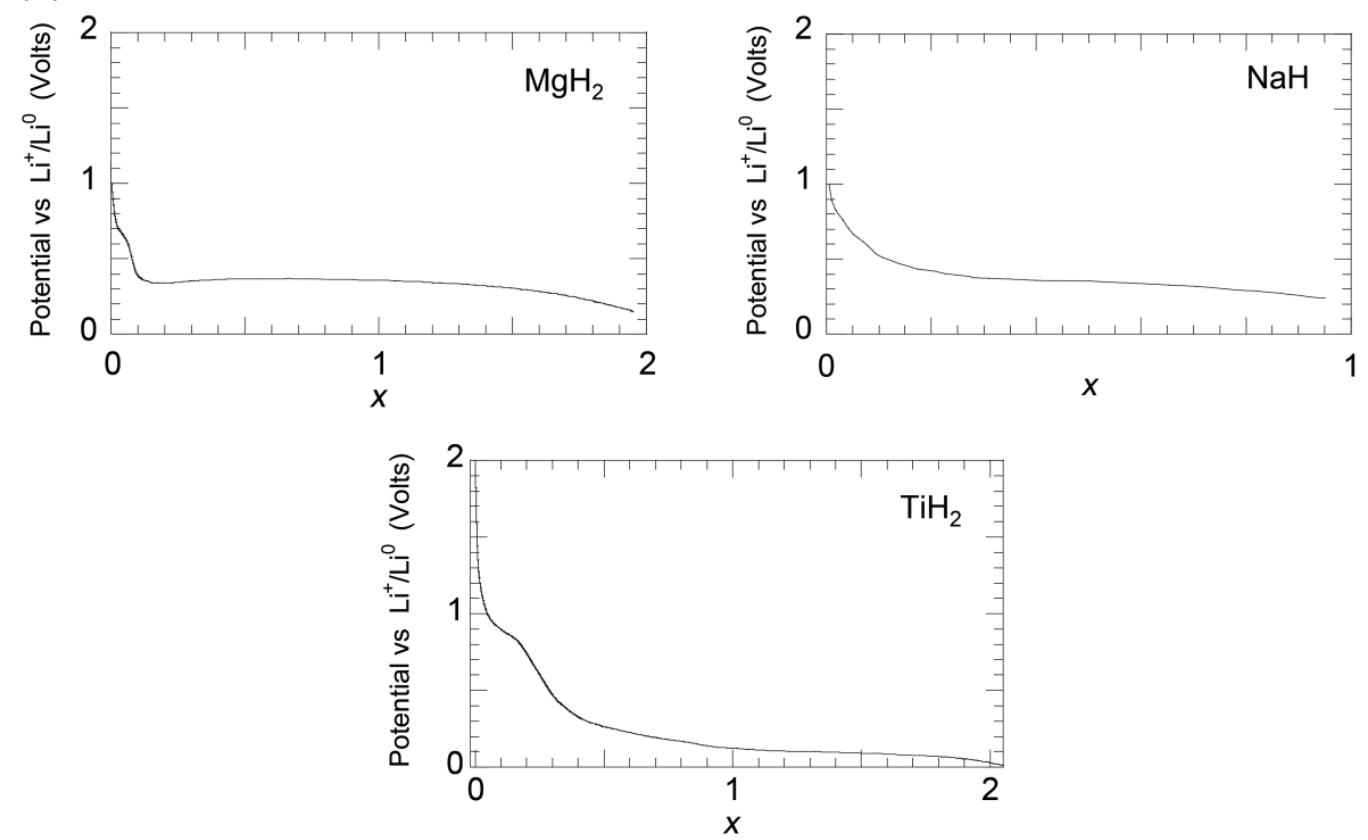

(b)
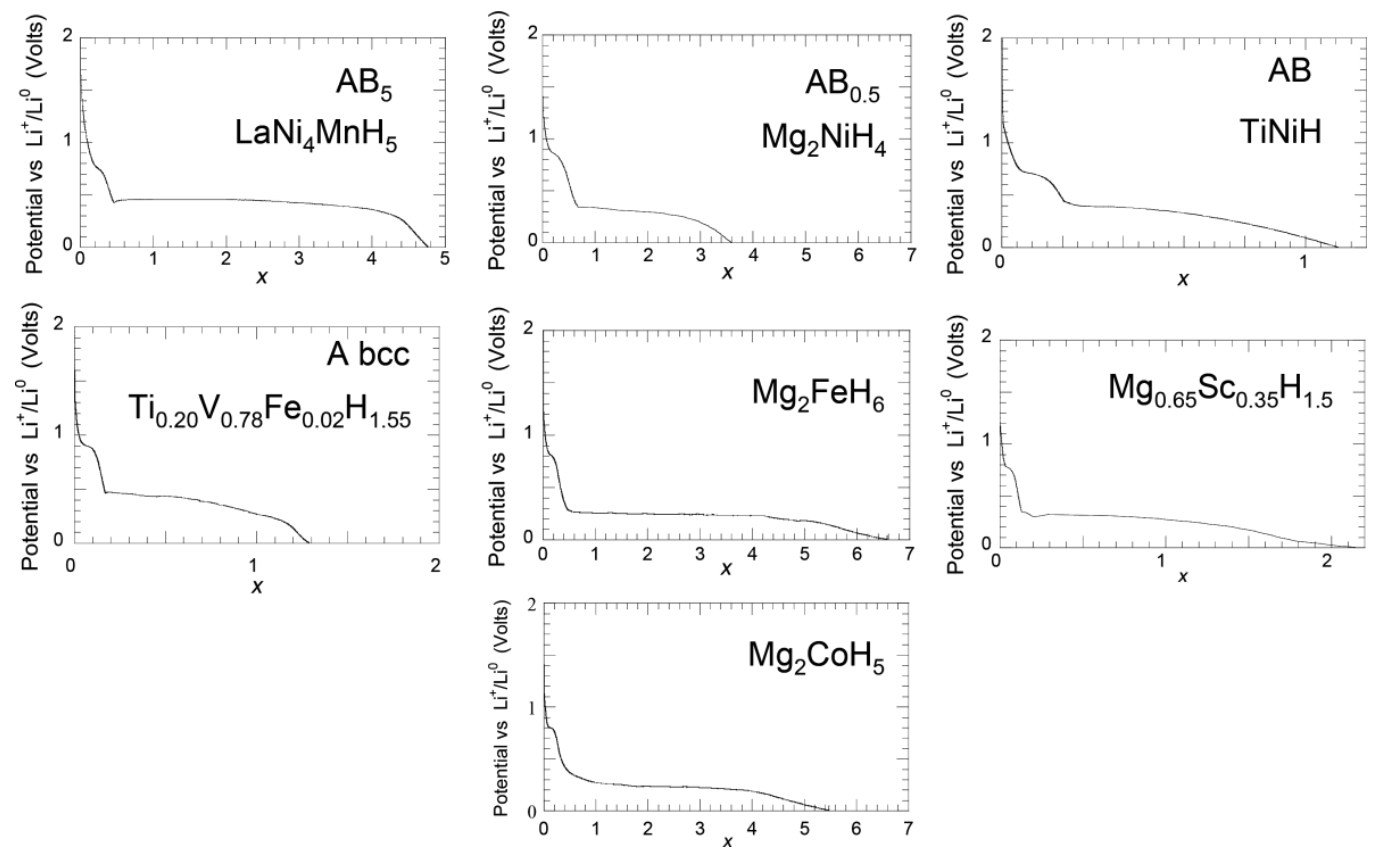

Figure 3: Potentials vs $\mathrm{Li}^{+} / \mathrm{Li}^{0}$ of $\mathrm{MH}_{x} / \mathrm{Li}$ cells $(\mathrm{V})$ as a function of the mole fraction of $\mathrm{Li}(x)$ recorded between 3 and $0.005 \mathrm{~V}$; (a) $\mathrm{MgH} \mathrm{H}_{2}, \mathrm{NaH}$ and $\mathrm{TiH}_{2}$, (b) $\mathrm{LaNi}_{4} \mathrm{MnH}_{5}, \mathrm{Ti}_{0 \cdot 20} \mathrm{~V}_{0.78} \mathrm{Fe}_{0.02} \mathrm{H}_{1.55}, \mathrm{Mg}_{2} \mathrm{NiH}_{4}, \mathrm{Mg}_{2} \mathrm{FeH}_{6}, \mathrm{Mg}_{2} \mathrm{CoH}_{5}, \mathrm{TiNiH}$, and $\mathrm{Mg}_{0.65} \mathrm{Sc}_{0.35} \mathrm{H}_{2.25}[11,79]$.

agreement with the formation of a Mg-type solid solution (Figure 4b, no. 6 and Table 1). The last slope corresponds to the formation of a bcc Li-type solid solution (Figure $4 \mathrm{~b}$, no. 8 ), and the plateau to the coexistence of both solid solution types ( $\mathrm{Li}$ and $\mathrm{Mg}$ ) (Figure 4b, no. 7). In short, $\mathrm{MgH}_{2}$ reacts with $\mathrm{Li}$ ions to form $\mathrm{Mg}$ and $\mathrm{LiH}$ within the conversion process $\mathrm{MgH}_{2}+2 \mathrm{Li}^{+}+2 \mathrm{e}^{-} \rightarrow \mathrm{Mg}+2 \mathrm{LiH}$ at around $0.44 \mathrm{~V} \mathrm{vs} \mathrm{Li}^{+} / \mathrm{Li}^{0}$.
Then the freshly formed $\mathrm{Mg}$ can react with $\mathrm{Li}$ ions at a low potential to form alloys (hep Mg-type and bcc Li-type solid solutions).

Li-Mg alloying reactions can be avoided by limiting the discharge curve to $x=2$ (Figure 5). In this case a reversible capacity of $1500 \mathrm{~mA} \cdot \mathrm{h}^{-1} \mathrm{~g}^{-1}$ (irreversible loss of $25 \%$ ) can be 

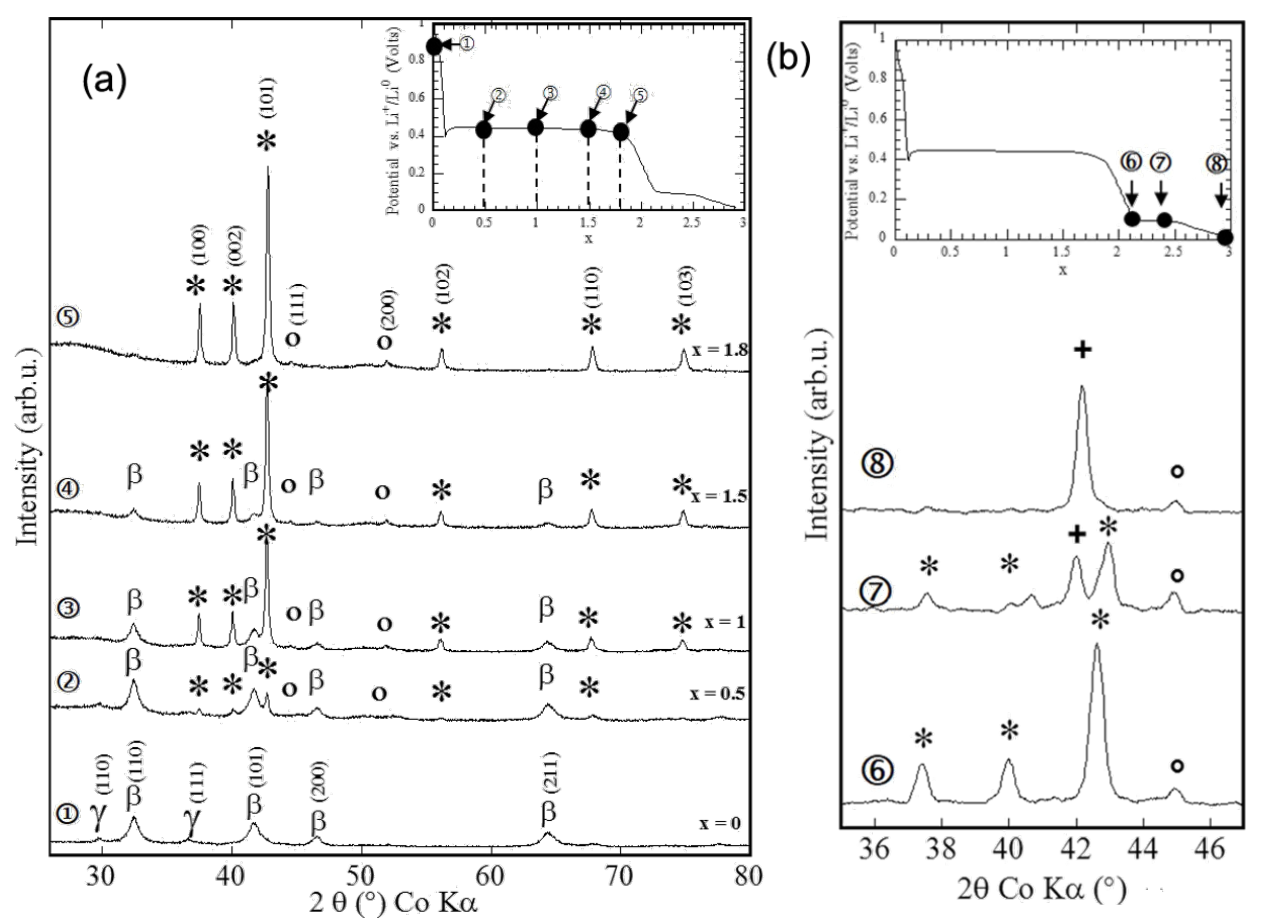

Figure 4: Potential profile and XRD patterns of $\mathrm{MgH}_{2}$ electrode at different stages of the conversion reaction. (a) Inset: Evolution of the potential ( $\mathrm{V}$ ) as a function of $x$ (mole fraction of $\mathrm{Li}$ ) for a $\mathrm{MgH}_{2}$ electrode cycled between 3 and $0.005 \mathrm{~V}$ at a rate of one equivalent of lithium in $100 \mathrm{~h}$. The recorded XRD patterns are associated with the various stages of the discharge, denoted by the numbers (1), (2), (3), (4) and (5) in panel and correspond to $x=0$ (starting electrode material), $x=0.5,1,1.5$ and 1.8 , respectively. The $X$-ray peaks marked by an asterisk, $\beta, y$ and circle correspond to Mg, $\beta-\mathrm{MgH}_{2}, \mathrm{Y}-\mathrm{MgH}_{2}$ and $\mathrm{LiH}$, respectively. b) Inset: Inset: Evolution of the potential (V) as a function of $x$ (mole fraction of Li) for a MgH $\mathrm{H}_{2}$ electrode cycled between 3 and $0.005 \mathrm{~V}$ at a rate of one equivalent of lithium in $100 \mathrm{~h}$. The XRD patterns (6), (7), and (8) corresponding to $x=2.1,2.35$ and 2.9 . The Bragg peaks marked by an asterisk and plus sign correspond to $\mathrm{Mg}(\mathrm{hcp})$ and $\mathrm{Li}$ (bcc) solid solutions, respectively. Adapted from [5] (copyright 2008 Nature Publishing Group) and [11].

(a)

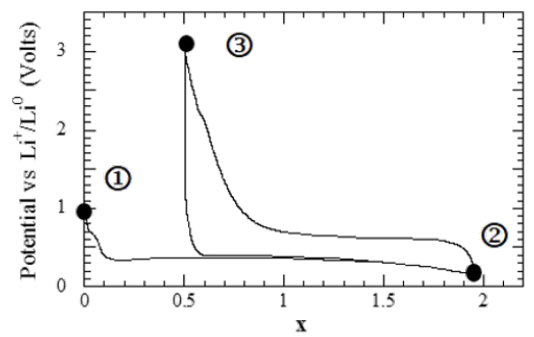

(b)

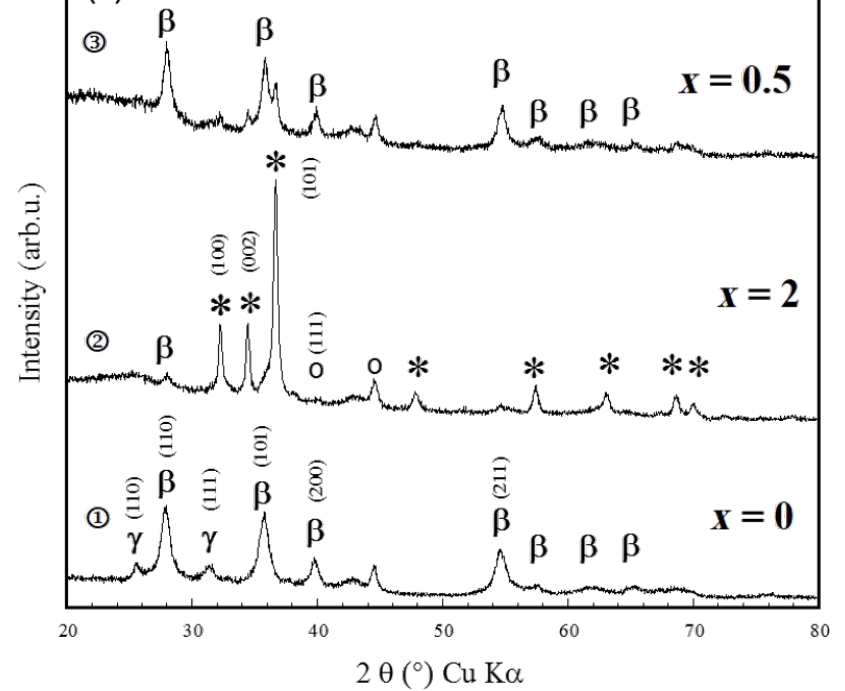

Figure 5: Potential profile and XRD patterns of $\mathrm{MgH}_{2}$ electrode at various stages of the conversion reaction. a) Evolution of the potential ( $\mathrm{V}$ ) as a function of $x$ for a Li/MgH 2 cell that was cycled down to $x=2$ at a rate of one equivalent of lithium in $10 \mathrm{~h}$. b) XRD patterns taken at various stages of the discharge, (1) $x=0$ (starting electrode material), (2) $x=2$ (end of the first discharge) and (3) $x=0.5$ (end of the first charge). The Bragg peaks marked by an asterisk, $\beta, \gamma$, and circle correspond to $\mathrm{Mg}, \beta-\mathrm{MgH}_{2}, \mathrm{Y}-\mathrm{MgH}_{2}$ and $\mathrm{LiH}$, respectively. Adapted from [5] (copyright $2008 \mathrm{Nature}$ Publishing Group) and [11]. 
Table 1: Lattice parameters for Mg and Mg-type solid solution formed during the reaction of $\mathrm{MgH}_{2}$ with $\mathrm{Li}$.

\begin{tabular}{ccc} 
& Mg & $\begin{array}{c}\text { Mg hcp solid } \\
\text { solution }\end{array}$ \\
\hline lattice parameters & $a=3.2090(3) \AA$ & $a=3.1970(2) \AA$ \\
& $c=5.2100(4) \AA$ & $c=5.1410(6) \AA$
\end{tabular}

obtained while a reversible capacity of $2700 \mathrm{~mA} \cdot \mathrm{h} \cdot \mathrm{g}^{-1}$ (irreversible loss $33 \%$ ) is measured for both processes (Figure 6).
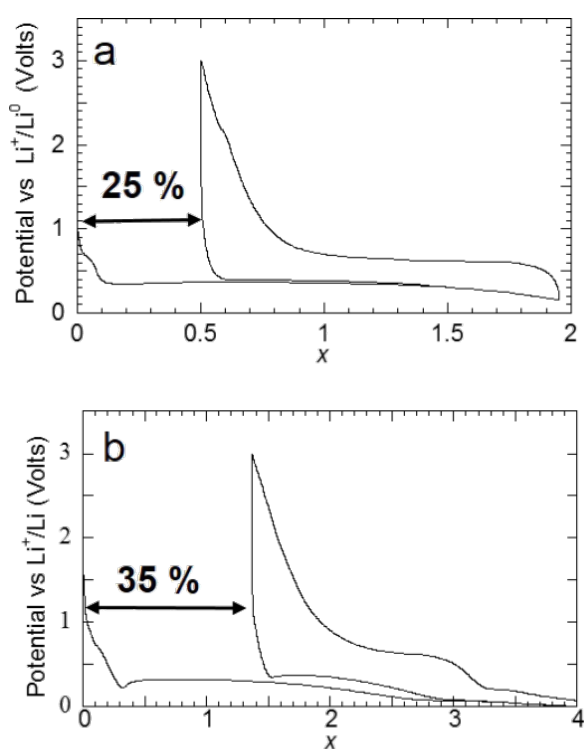

Figure 6: Potential profile of a $\mathrm{MgH}_{2}$ electrode at various stages of the conversion reaction. a) Evolution of the potential (V) as a function of $x$ for a $\mathrm{Li} / \mathrm{MgH}_{2}$ cell that was cycled down to $x=2$ at a rate of one equivalent of lithium in $10 \mathrm{~h}$. b) Evolution of the potential (V) as a function of $x$ for a Li/MgH $\mathrm{Mell}_{2}$ that was cycled down to $x=4$ at a rate of one equivalent of lithium in $10 \mathrm{~h}$. Adapted from [5] (copyright 2008 Nature Publishing Group) and [11].

\section{II.2 Reaction of $\mathrm{TiH}_{2}$ with lithium}

The study of the reactions of titanium hydride with lithium is motivated by the chemical and structural properties of $\mathrm{TiH}_{2}$ [10]. As shown on Figure 1, $\mathrm{TiH}_{2}$ is attractive regarding its high theoretical capacities (like all binary hydrides). In addition, an improvement of the conversion process kinetics is expected because of the good electrode conductivity due to the metallic properties of titanium hydride. This reaction can be studied without any parasite reaction as Ti does not form alloys with lithium.

The $\mathrm{TiH}_{2}$ discharge capacity, presented in Figure 7, drastically differs from that of $\mathrm{MgH}_{2}$ through the presence of two slopes prior to a pseudo plateau. XRD analyses of the electrode during electrochemical discharge show that the reaction of $\mathrm{TiH}_{2}$ with $\mathrm{Li}$ involves three steps. The two first slopes correspond to the formation of an $\mathrm{fcc} \delta-\mathrm{TiH}_{2-x}$ solid solution until $x=0.34$ (first slope) that transforms partially from $x=0.34$ to 1 in a distorted face-centered orthorhombic phase $\delta$-TiH (fco) (second slope). Note that from $x=0.34$ to 1 , the peritectic transformation: hep $\alpha-\mathrm{Ti}(\mathrm{H}) \rightarrow$ fcc $\delta$ - $\mathrm{TiH}_{2-x}+\delta$-TiH explains hexagonal closepacked (hcp) $\alpha$-formation absence. Finally, conversion process occurs in the pseudo plateau with the formation of hcp $\alpha$-Ti and LiH.

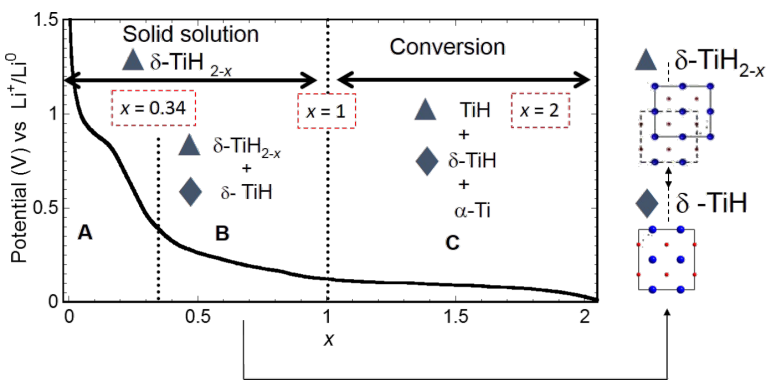

Figure 7: Summary of the dehydrogenation process of $\mathrm{TiH}_{2}$ electrode $\delta-\mathrm{TiH}_{2-x}$ (fcc): black triangles, $\mathrm{TiH}$ (fco): black diamonds, projection along the $b$-axis of $\delta-\mathrm{TiH}_{2-x}$ (fcc): black triangles and $\mathrm{TiH}$ (fco): black diamonds showing the relationship between fcc (black triangles) and fco (black triangles) structures. Adapted from [10] (copyright 2012 Elsevier) and [11].

\section{II.3 Reaction of $\mathrm{Mg}_{2} \mathrm{MH}_{x}$ with lithium}

After studying the reaction of titanium hydride with lithium, during which a reaction path involving the formation of the metastable fco $\delta$-TiH phase occurs, the complex hydrides $\mathrm{Mg}_{2} \mathrm{FeH}_{6}, \mathrm{Mg}_{2} \mathrm{CoH}_{5}, \mathrm{Mg}_{2} \mathrm{NiH}_{4}$ were chosen as models system for a conversion process with high energy storage capacities and unusual thermodynamics properties $[13,19]$. In fact, the decomposition of $\mathrm{Mg}_{2} \mathrm{FeH}_{6}$ and $\mathrm{Mg}_{2} \mathrm{CoH}_{5}$, which is expected during their electrochemical reaction with lithium, can be used for the formation of a conductive Fe or Co matrix, which is helpful to reverse the reaction between $\mathrm{Mg}$ and $\mathrm{LiH}$. In addition, the far-from-equilibrium electrochemical process is an interesting tool to search for new intermetallic compounds consisting of $\mathrm{Mg}$ and $\mathrm{Fe}$ or $\mathrm{Co}$ [20,21]. As shown in Section I.3, $\mathrm{Mg}_{2} \mathrm{MH}_{x}(\mathrm{M}=\mathrm{Fe}, \mathrm{Co}, \mathrm{Ni}, x=6,5,4)$ react with lithium at

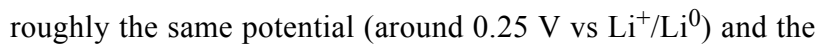
capacities measured during the discharge are close to the theoretically obtained values (Figure 8). From a structural point of view, a common behavior can be noticed for the reaction of lithium with all complex hydrides from the XRD characterizations of the electrodes. A complete (for the case of $\mathrm{Mg}_{2} \mathrm{FeH}_{6}$ ) or partial disappearance of the parent phases is observed, which occurs without any formation of metals (Figure 9). This loss of 
crystallinity suggests the formation of an electrode with nanocrystalline or amorphous structure. The formation of nanoscale Fe during the decomposition of $\mathrm{Mg}_{2} \mathrm{FeH}_{6}$ is confirmed by XAS and Mössbauer spectroscopy [22]. Ex situ XAS spectroscopy of the $\mathrm{Mg}_{2} \mathrm{CoH}_{5}$ and $\mathrm{Mg}_{2} \mathrm{NiH}_{4}$ electrodes revealed the formation of disordered $\mathrm{MgCo}$ and $\mathrm{Mg}_{2} \mathrm{Ni}$ intermetallic compounds.

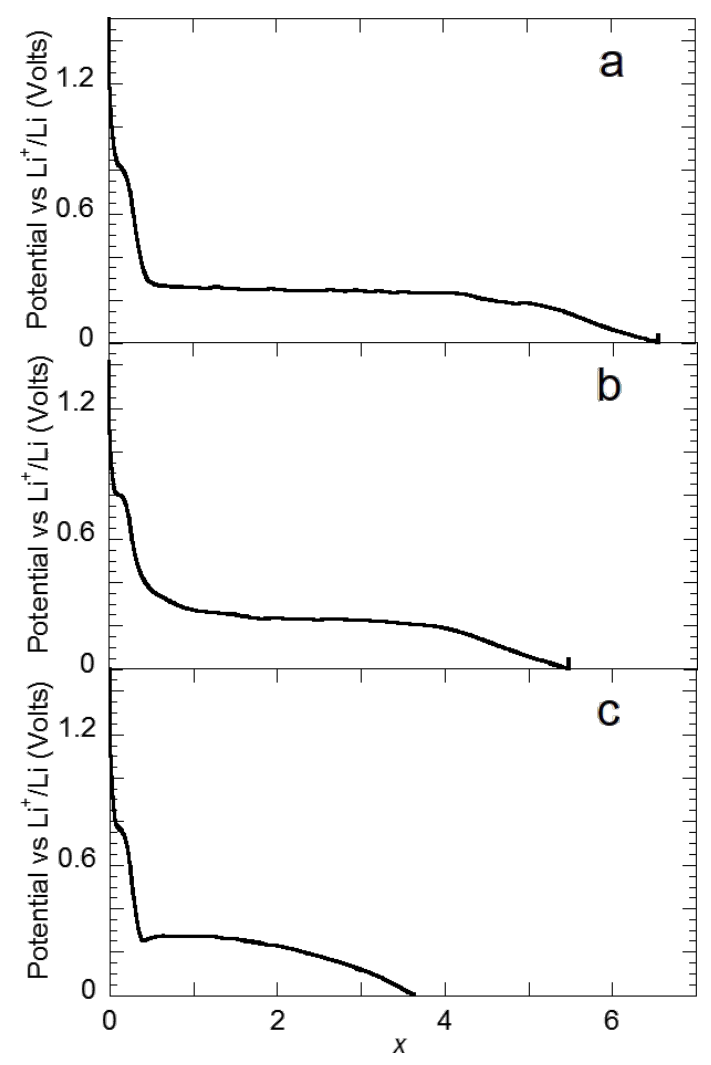

Figure 8: Discharge curves for a) $\mathrm{Mg}_{2} \mathrm{FeH}_{6}$, b) $\mathrm{Mg}_{2} \mathrm{CoH}_{5}$ and c) $\mathrm{Mg}_{2} \mathrm{NiH}_{4}$ electrodes prepared by reactive grinding as a function of $\mathrm{Li}$ (x) mole fraction, recorded at a current rate of one equivalent of $\mathrm{Li}$ in $10 \mathrm{~h}$. Adapted from [13] (copyright 2013 Elsevier) and [19].

The intensity reduction of the XRD lines, which occurs without broadening, involves shifts of the lattice parameters. For instance, the $\mathrm{Mg}_{2} \mathrm{CoH}_{5}$ lattice parameters $a$ and $c$ rise until $x=1$ (from 4.4940(3) to 4.517(2) $\AA$ and from 6.582(1) to 6.608(1) $\AA$, respectively; a cell volume expansion of $1.44 \%$ ), evoking a phase transformation. For $\mathrm{Mg}_{2} \mathrm{NiH}_{4}$ the lattice parameter $c$ decreases from 6.538(1) to 6.477(2) $\AA$, which is concomitant with a phase transformation involving a low-hydrogen-content hydride for $x \leq 3: \mathrm{Mg}_{2} \mathrm{NiH}_{4} \rightarrow \mathrm{Mg}_{2} \mathrm{NiH}[23,24]$.

The reaction mechanism can therefore be summarized as follows:

$$
\begin{aligned}
\mathrm{Mg}_{2} \mathrm{FeH}_{6}+6 \mathrm{Li} & \rightarrow 2 \mathrm{Mg}+\text { amorphous } \mathrm{Fe}+6 \mathrm{LiH}, \\
\mathrm{Mg}_{2} \mathrm{CoH}_{5}+5 \mathrm{Li} & \rightarrow \mathrm{Mg}+\text { disordered } \mathrm{MgCo}+5 \mathrm{LiH} \\
\mathrm{Mg}_{2} \mathrm{NiH}_{4}+3 \mathrm{Li} & \rightarrow \mathrm{Mg}_{2} \mathrm{NiH}+3 \mathrm{LiH}+\mathrm{Li} \\
& \rightarrow \text { disordered } \mathrm{Mg}_{2} \mathrm{Ni}+4 \mathrm{LiH} .
\end{aligned}
$$

The reaction with $\mathrm{Mg}_{2} \mathrm{FeH}_{6}$ during the conversion process with lithium ions is the first example for the production of an amorphous phase " $2 \mathrm{Mg}+\mathrm{Fe}$ ".

\section{II.4 Reaction of other Mg-based hydrides with lithium}

The reactions of $2 \mathrm{MgH}_{2}+\mathrm{M}(\mathrm{M}=\mathrm{Cu}, \mathrm{Si})$ and $0.65 \mathrm{Mg}+$ $0.35 \mathrm{M}\left(\mathrm{M}=\mathrm{ScH}_{2}, \mathrm{Ti}\right)$ mixtures prepared by reactive grinding under 90 bar of hydrogen pressure with lithium ions were also studied [19,25-27]. The electrochemical behavior of $\mathrm{MgH}_{2}$ is not affected by the presence of a second element, $\mathrm{Cu}$ or $\mathrm{Si}$, and significant reversible capacities for the conversion process $\left(>1000 \mathrm{~mA} \cdot \mathrm{h} \cdot \mathrm{g}^{-1}\right)$ are obtained. In the case of the mixture $2 \mathrm{MgH}_{2}+\mathrm{Si}$, an additional capacity below $0.2 \mathrm{~V} \mathrm{vs} \mathrm{Li}^{+} / \mathrm{Li}^{0}$ due to the alloying reaction of $\mathrm{Si}$ with $\mathrm{Li}$ is observed. This combined conversion $\left(\mathrm{MgH}_{2}\right)$ /alloying ( $\mathrm{Si}$ ) system presents the highest theoretical capacity anode with the possibility to reach approximately $6000 \mathrm{~mA} \cdot \mathrm{h} \cdot \mathrm{g}^{-1}$.

The production of pure $\mathrm{Mg}_{0.65} \mathrm{Sc}_{0.35} \mathrm{H}_{2.25}\left(1900 \mathrm{~mA} \cdot \mathrm{h} \cdot \mathrm{g}^{-1}\right)$ by reactive grinding from magnesium and scandium hydride $\left(\mathrm{MgH}_{2}+\mathrm{ScH}_{2}\right)$ is not possible. Instead, a mixture of $68 \%$ of $\mathrm{Mg}_{0.65} \mathrm{Sc}_{0.35} \mathrm{H}_{2.25}, 20 \%$ of $\mathrm{MgH}_{2}$ and $12 \% \mathrm{Mg}_{2} \mathrm{FeH}_{6}$ is obtained. The formation of $\mathrm{Mg}_{2} \mathrm{FeH}_{6}$ is due to the strong abrasion of the grinding tools through scandium hydride. The discharge curves of this hydride mixture involves $2.25 \mathrm{Li}$ at $0.32 \mathrm{~V} \mathrm{vs} \mathrm{Li}^{+} / \mathrm{Li}^{0}$ and the corresponding X-ray diffraction pattern obtained at the end of the discharge shows the presence of both $\mathrm{Mg}_{0.65} \mathrm{Sc}_{0.35} \mathrm{H}_{0.8}$ and $\mathrm{Mg}_{0.65} \mathrm{~S}_{0.35} \mathrm{H}_{1.5}$ cubic phases in agreement with the results obtained in $\mathrm{KOH}$ electrolyte and reported by Notten et al. [28].

Such desirable electrochemical behavior is also obtained with the $\mathrm{Mg}_{0.65} \mathrm{Ti}_{0.35} \mathrm{H}_{2.25}$ mixture prepared by reactive grinding with a reversible conversion process involving both $\mathrm{MgH}_{2}$ and $\mathrm{TiH}_{2}$ without the addition of carbon. As expected, $\mathrm{TiH}_{2}$ increases the conductivity of the electrode and a full discharge process is obtained without carbon. The development of such Mg-based system appears to be a promising opportunity.

\section{Kinetics limitations of hydrides for conversion reactions: example of $\mathrm{MgH}_{2}$}

The huge numbers of hydrides reported in the literature exhibit different structures, electronic properties and thermodynamics stabilities. Using the hydrides classification proposed by 

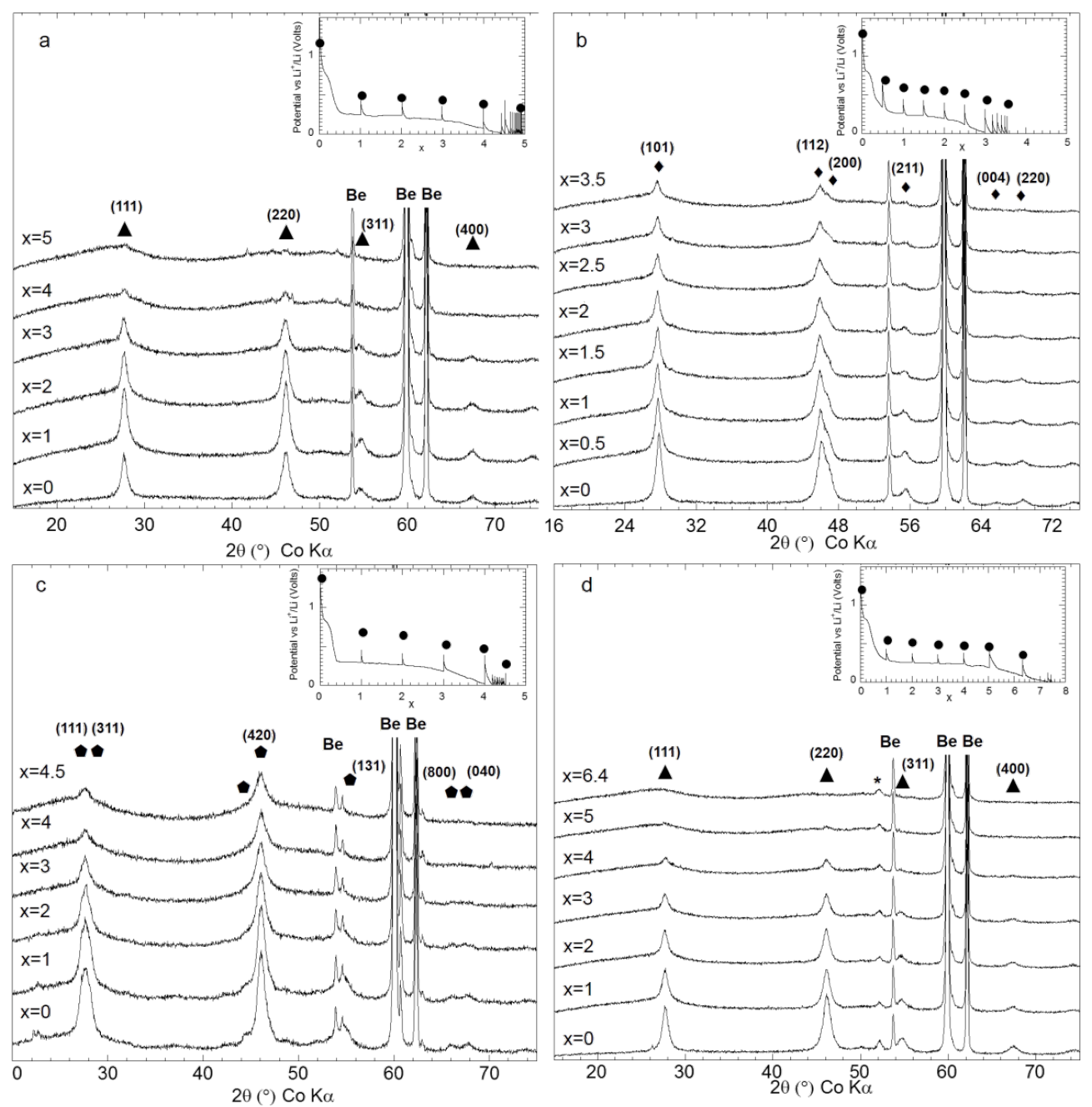

Figure 9: In situ XRD patterns of a) $\mathrm{Mg}_{2} \mathrm{FeH}_{6}$, b) $\mathrm{Mg}_{2} \mathrm{CoH}_{5}$ and c) $\mathrm{Mg}_{2} \mathrm{NiH}_{4}$ and d) $\mathrm{Mg}_{2} \mathrm{FeH}_{6}-10 \%$ Ct, $\mathrm{z}$ electrodes prepared by reactive grinding as a function of the mole fraction of $\mathrm{Li}(x)$ Inset: Potential profile of a) b) c) and d) obtained during GITT (rate: one equivalent of Li in $10 \mathrm{~h}$, relaxation time: $10 \mathrm{~h}$ ). Adapted from [13] (copyright 2013 Elsevier) and [19].

Libowitz et al. [29,30] metallic, covalent and ionic hydrides can be identified.

Given the fact that the electric behavior is an important parameter for the electrochemical reaction, the issue of the poor electric conductivity of ionic and iono-covalent hydrides must be solved. For instance, the ionic hydride $\mathrm{MgH}_{2}$ exist as $\alpha, \beta$ and $\gamma$, with the space groups $\mathrm{P}_{2} / \mathrm{mnm}$ (tetragonal, $a=b=4.516 \AA, c=3.020 \AA$ ) $P a-3$ (cubic) and $P b c n$ (orthorhombic, $a=4.526 \AA, b=5.448 \AA, c=4.936 \AA$ ), respectively. The tetragonal phase is the more stable phase. These hydrides exhibit band gap energies of 5.3, 5.6 and $4.2 \mathrm{eV}$, respectively, and are not electronic conductors but insulators [31]

Figure 10 shows the poor electrochemical reactivity of commercially available tetragonal $\mathrm{MgH}_{2} \mathrm{vs} \mathrm{Li}^{+} / \mathrm{Li}^{0}$, with no electro- chemical capacity during the first discharge. The addition of an electronic conductive material, such as the graphite Super P (electronic conductivity: $10^{3} \mathrm{~S} \cdot \mathrm{cm}^{-1}$ ) increases the electronic conductivity of the electrode. As presented in Figure 10a, the discharge capacity of the hydride increases with the amount of graphite. The addition of $25 \%$ of graphite gives a discharge capacity of $1.4 \mathrm{Li}$ for $2 \mathrm{~h}$ for a current of one mole of electron in $100 \mathrm{~h}$. The contribution of Super P carbon to the total capacity remains very small and the maximum of the contribution that can be reached is less or equal to $x=0.25$.

Note that the conductivity of the electrode is not only influenced by $\mathrm{MgH}_{2}$ but also by conducting metallic $\mathrm{Mg}$ and insulating $\mathrm{LiH}$, which are generated during the reaction. The improvement of the poor electronic conductivity of the active material in powder form has been widely addressed in the litera- 

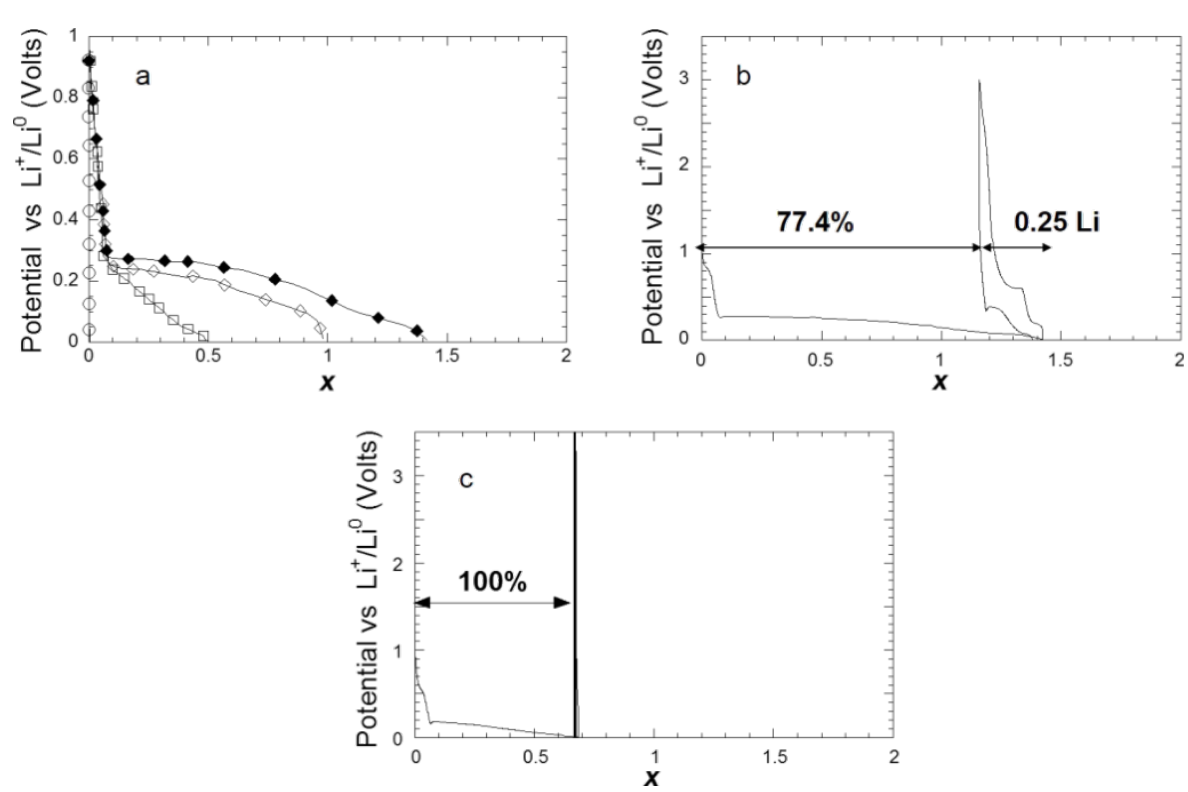

Figure 10: The evolution of the potential $(\mathrm{V})$ as a function of $x$ (mole fraction of $\mathrm{Li}$ ) for a $\mathrm{MgH}_{2}$ electrode prepared with commercial hydride cycled between 3 and $0.005 \mathrm{~V}$. a) Discharge curves at a rate of one equivalent of lithium in $100 \mathrm{~h}$ as function of the content of Super $\mathrm{p}$ carbon of the electrode: open circles: $0 \%$, open squares: $15 \%$, open diamonds: $20 \%$, black diamonds: $25 \%$. b) Discharge-charge curve at a rate of one equivalent of lithium in $100 \mathrm{~h}$ for a content of $25 \%$ of Super $\mathrm{P}$ carbon. c) Discharge-charge curve at a rate of one lithium in $10 \mathrm{~h}$ for a content of $25 \%$ of Super $\mathrm{P}$ carbon at a rate of one lithium in $10 \mathrm{~h}$ [11].

ture for different electrode materials (in aqueous and nonaqueous electrolytes). A solution is carbon-coating through chemical or physical methods. For electrochemical reactions carried out in thin films in $\mathrm{KOH}$ electrolyte with non-conductive hydrides such as $\mathrm{MgH}_{2}$, or $\mathrm{Mg}_{2} \mathrm{NiH}_{4}$, the presence of a small amount of non-hydrogenated compound (few percent), as $\mathrm{Mg}$ or $\mathrm{Mg}_{2} \mathrm{Ni}$, in the starting material is sufficient to produce a satisfactory electronic conductivity inside the electrode and the addition of carbon is not necessary. Another issue consists in the production of ternary hydrides films with $\mathrm{Mg}$, $\mathrm{Ti}$ and $\mathrm{H}$ $[32,33]$. The metallic behavior $\mathrm{TiH}_{2}$ counters the insulating influence of $\mathrm{MgH}_{2}$.

\section{III.1 Influence of the particle size on the reversibility of the conversion process}

Regarding the reversibility of the conversion reaction, the poor capacities obtained during the first charge for electrodes composed of commercial $\mathrm{MgH}_{2}(0 \mathrm{Li}$ and $0.25 \mathrm{Li}$ for a current rate of one equivalent of $\mathrm{Li}$ in 10 and $100 \mathrm{~h}$, respectively) clearly show than the benefit of the addition of Super P carbon to the electronic conductivity of the active material seems completely lost when the reaction is inversed (Figure 10b,c)

Other parameters than the conductivity of the active material also govern the efficiency of the conversion process. In fact, the volume variation of the electrode during the conversion process $\mathrm{MH}_{x}+x \mathrm{Li}^{+}+x \mathrm{e}^{-} \rightarrow \mathrm{M}^{0}+x \mathrm{LiH}$ drastically affects the con- ductivity between the particles. For $\mathrm{MgH}_{2}$ the volume variation is $83 \%$ between $\mathrm{MgH}_{2}\left(61.59 \AA^{3}\right)$ and $\operatorname{Mg}\left(46.46 \AA^{3}\right)+2 \mathrm{LiH}\left(2 \times 33.3 \AA^{3}\right)$. Thus, during the discharge the electrode volume increases with the lithium transfer and decreases during the lithium extraction. As a consequence, voids are created inside the electrode and disconnect the particles from each other and from the current collector at the same time. Decreasing the particle size is one way to accommodate for the volume variation of the electrode and to maintain cohesion of the interfaces and the connection between particles and the current collector. Reducing the length of diffusion for $\mathrm{Li}$ and $\mathrm{H}$ can be helpful for volume accommodation and preserving interfaces. Different approaches to reduce the particles sizes and to accommodate the volume variation of the electrode can be considered and will be presented in the following paragraph: Effect of grinding on commercial hydride, effect of three hydrogen sorption, effect of grinding commercial hydride with carbon, effect of activation by sorption cycles follow by the grinding with carbon, reactive milling.

\section{III.2 Effect of mechanical grinding on commercial $\mathrm{MgH}_{2}$}

Grinding of commercial $\mathrm{MgH}_{2}$ enables a faster hydrogen desorption with a desorption maximum at $372{ }^{\circ} \mathrm{C}$ compared to $445{ }^{\circ} \mathrm{C}$ for the untreated commercial material (Figure 11a). As expected, discharge efficiency increases with the amount of Super P carbon added to the electrode (Figure 11b). In this case, 

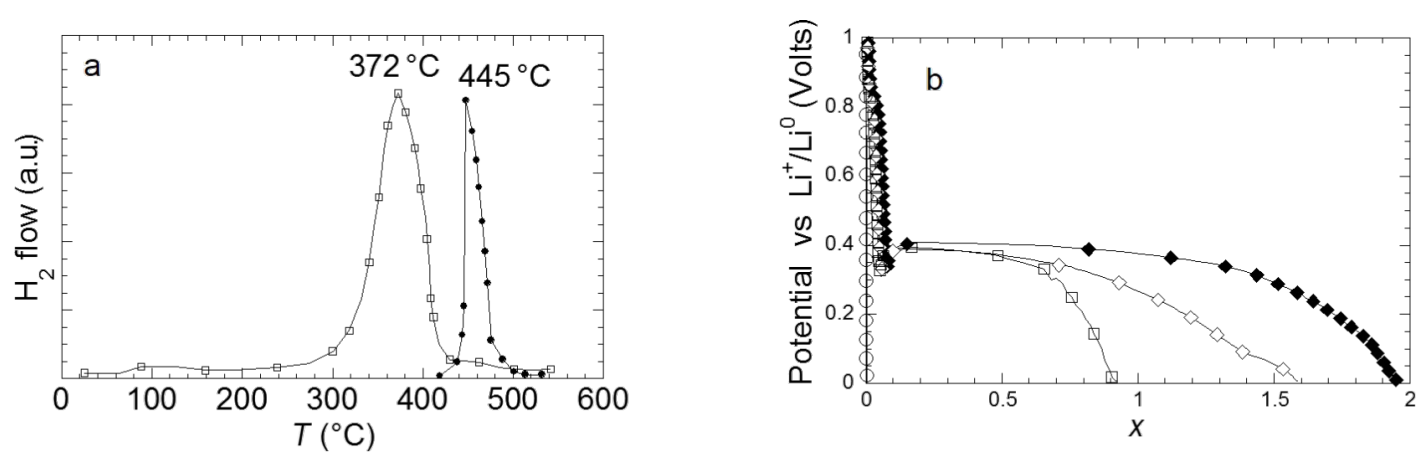

Figure 11: a) DSC traces of commercial $\mathrm{MgH}_{2}$ unground and ground for $20 \mathrm{~h}$. b) Evolution of the potential (V) as a function of $x$ (mole fraction of Li) for a $\mathrm{MgH}_{2}$ electrode prepared with commercial hydride ground for $20 \mathrm{~h}$ in the Spex mixer mill and cycled between 3 and $0.005 \mathrm{~V}$ at a rate of one equivalent of lithium in $100 \mathrm{~h}$. Super $\mathrm{P}$ carbon content (\%) of the electrode: open circles: $0 \%$, open squares: $15 \%$, open diamonds: $20 \%$, black diamonds: $25 \%$ [11].

a full discharge capacity of $x=1.95 \mathrm{Li}$ can be achieved when $25 \%$ of graphite is added. The improved performance of the ground sample is due to a reduction of the crystallite size down to few nanometers, which facilitates the diffusion of hydrogen and lithium by increasing the number of diffusion paths. However, despite an improvement of the discharge kinetic, the reversibility of the hydride is hardly changed (Figure 12a). The reversible capacity of ground commercial $\mathrm{MgH}_{2}$ after $30 \mathrm{~h}$ of grinding is actually $x=0.26 \mathrm{Li}$.

The particle size cannot be reduced below $0.1 \mu \mathrm{m}$ through grinding, because immediate agglomeration of smaller particles occurs (Figure $12 \mathrm{~b}, \mathrm{c}$ ). So, even if crystallite size of few nanometers can be reached during grinding, the formation of agglomerates of 5 to $30 \mu \mathrm{m}$ (consisting of primary particles of $0.1-5 \mu \mathrm{m}$, Figure $12 \mathrm{~b}$ ) limits the reversibility of the conversion process.

\section{III.3 Effect of hydrogen sorption cycles on $\mathrm{MgH}_{2}$}

The particle size of the hydride is also reduced through decrepitation during hydrogen desorption-absorption cycles. This solid-gas reaction not only reduces the particle size of the hydride but also enhances its reactivity vs Li-ions. In the case of the system $\mathrm{Mg} / \mathrm{MgH}_{2}, 5 \%$ of Super P carbon was mixed with the $\mathrm{Mg}$ powder in order to increase the thermal conductivity of the powder and to prevent the necking of particles during sorption cycles.

Figure 13a and Figure 13b show the hydrogen sorption kinetics at $350{ }^{\circ} \mathrm{C}$ for $\mathrm{Mg} / \mathrm{MgH}_{2}$ for the first and the third cycles (uptake and loss in wt \% hydrogen). Hydrogen sorption kinetics and capacities increase from the first to the third cycle and then are constant for the subsequent cycles (not shown here). This activation process observed during the first three cycles can be correlated with a particle size reduction (Figure $13 \mathrm{c}$ and
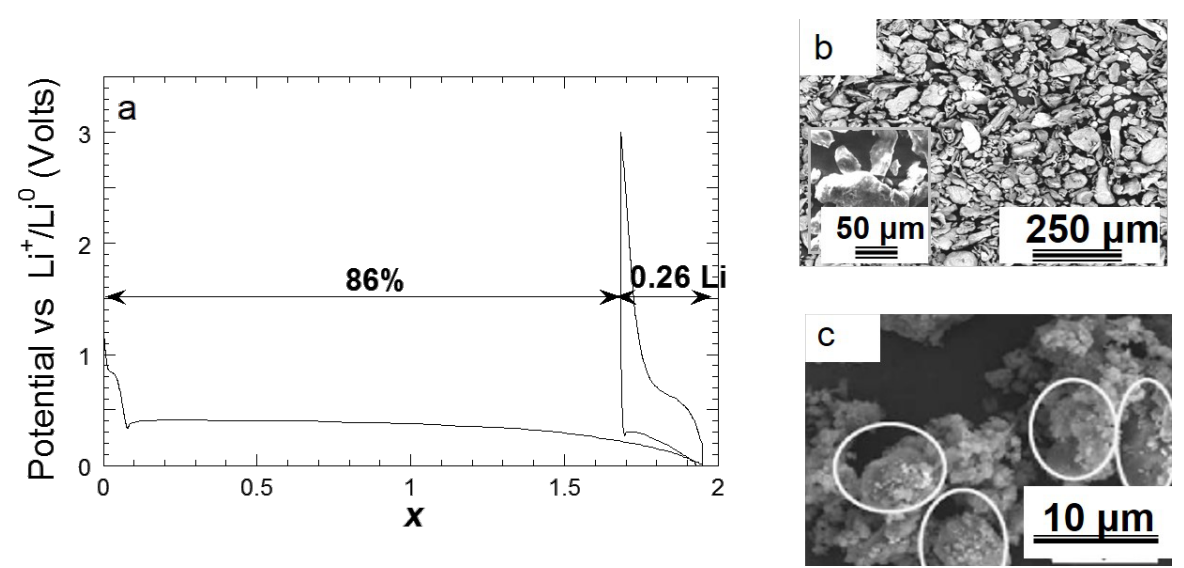

Figure 12: a) Evolution of the potential $(\mathrm{V})$ as a function of $x$ (mole fraction of $\mathrm{Li}$ ) for a $\mathrm{MgH}_{2}$ electrode prepared with commercial hydride, ground $30 \mathrm{~h}$ in a Spex mixer mill and cycled between 3 and $0.005 \mathrm{~V}$ at a rate of one equivalent of lithium in $100 \mathrm{~h}$. b) SEM image of a MgH $\mathrm{H}_{2} \mathrm{Commercial} \mathrm{powder}$ ground $30 \mathrm{~h}$ in the Spex mixer mill. c) SEM image of $\mathrm{MgH}_{2}$ commercial powder ground $30 \mathrm{~h}$ in the Spex mixer mill showing the agglomeration of particles [11]. 

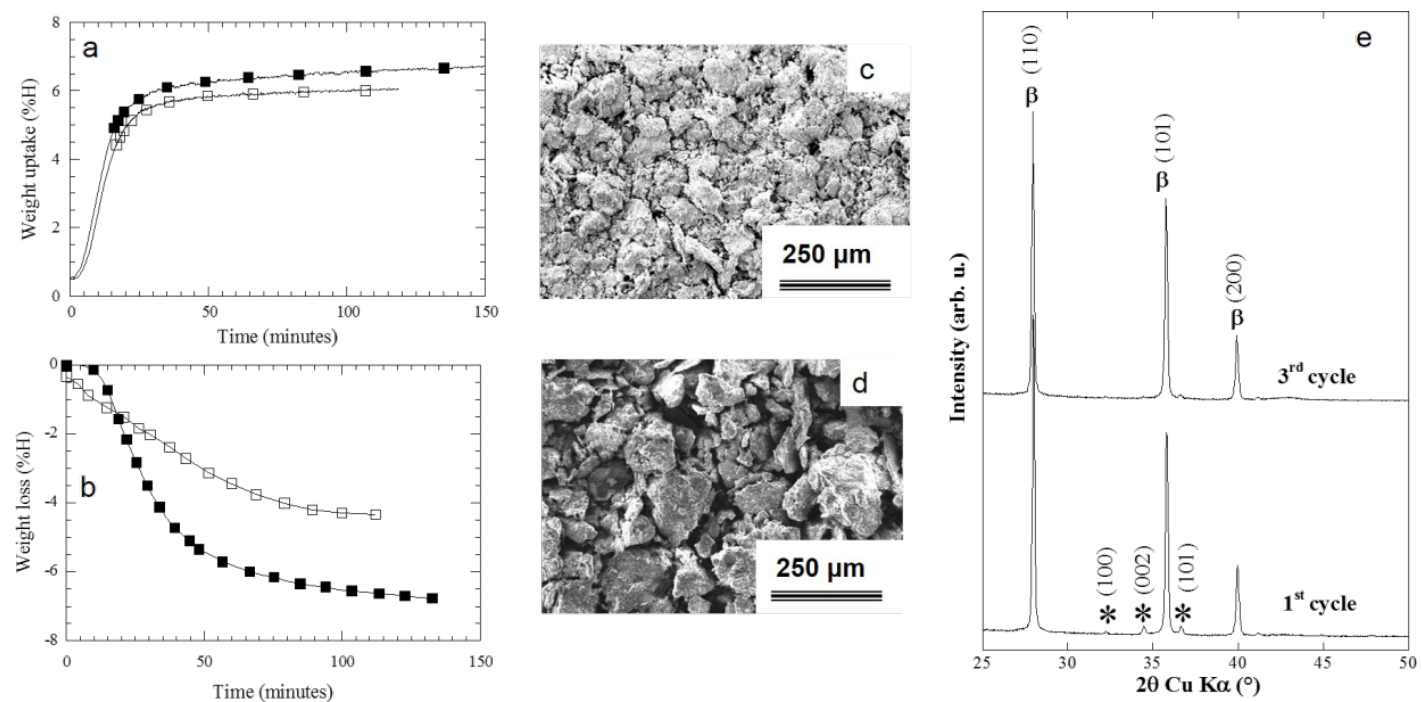

Figure 13: a) Absorption and b) desorption kinetics at $350{ }^{\circ} \mathrm{C}$ for $\mathrm{Mg}-10 \% \mathrm{C}_{10,320}$ composite (open squares): first cycle, black squares: third cycle; c) SEM image of the $\mathrm{MgH}_{2}$ powder after one absorption; d) SEM image of the $\mathrm{MgH}_{2}$ powder after three absorptions; e) XRD patterns of the MgH powder after one and after three absorptions [11].

Figure 13d) and an increase of the BET surface area from 7 to $14 \mathrm{~m}^{2} \cdot \mathrm{g}^{-1}$ while no change of the hydride crystallinity is observed (Figure 13e).

The effect of three sorption cycles on the reaction of $\mathrm{MgH}_{2}$ with lithium (Figure 14) shows that reversible capacity drastically increases compared to that of ground commercial hydride and reaches $0.88 \mathrm{Li}$ after three sorption cycles (Figure 14c). Despite an attractive increase of reversible capacity, an irreversible loss $(48 \%)$ can be noticed on potential-capacity curves.

\section{III.4 Effect of grinding of $\mathrm{MgH}_{2}$ with carbon}

Grinding of commercial $\mathrm{MgH}_{2}$ with a pre-ground $\mathrm{C}_{t, z}$ carbon, where $t$ refers to the pre-grinding time and $z$ to the carbon BET surface area, was used to enhance the efficiency of the conversion reaction. Grinding of commercial $\mathrm{MgH}_{2}$ with $\mathrm{C}_{t, z}$ carbon is supposed to create of a porosity volume inside the electrode, corresponding to a volume increase due to matter transfer. This porous volume is then recovered during the lithium extraction and the total volume change of the electrode is then minimized. In addition, the carbon also acts as conductive additive and a coating agent, which prevents the agglomeration of the hydride particles during grinding. A detailed study of the effect of mechanical milling on the physical/chemical and electrochemical properties compared to $\mathrm{AB}_{5}$ alloys is available in [34].

Figure 15 shows the evolution of the BET surface $z$ (in $\mathrm{m}^{2} \cdot \mathrm{g}^{-1}$ ) and of the $d(002)$ interplanar spacing of carbon $\mathrm{C}_{t, z}$, as a function of the milling time $t$ (in $\mathrm{h}$ ). Two main grinding steps can be noticed in Figure 15. First the BET surface area increase while
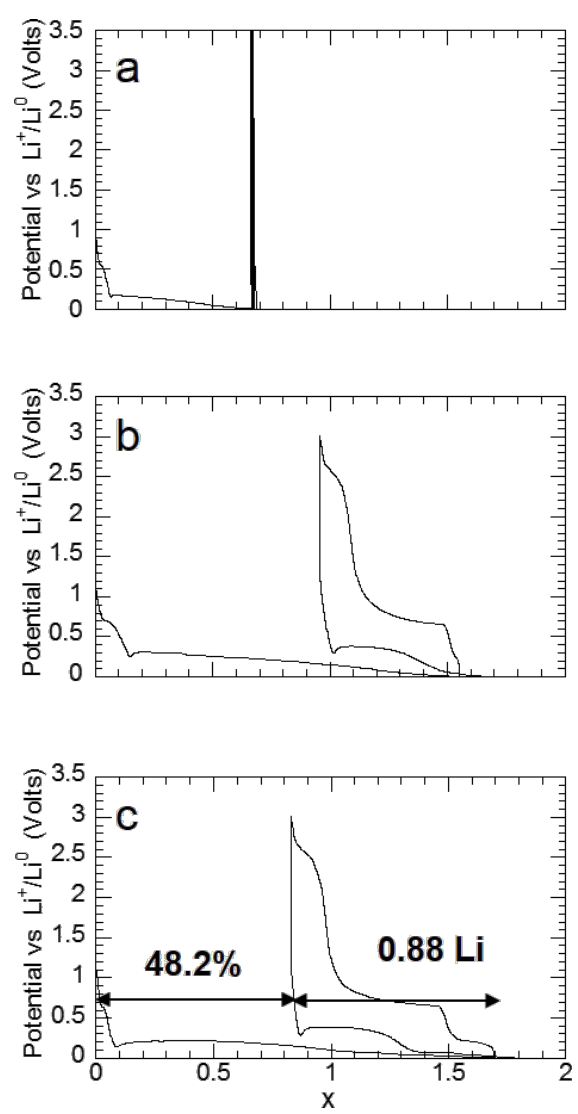

Figure 14: Evolution of the potential $(V)$ as a function of $x$ (mole fraction of $\mathrm{Li}$ ) for $\mathrm{MgH}_{2}$ electrodes cycled between 3 and $0.005 \mathrm{~V}$ at a rate of one equivalent of lithium in $10 \mathrm{~h}$. a) $\mathrm{MgH}_{2}$ commercial hydride; b) $\mathrm{MgH}_{2}$ obtained after one absorption of hydrogen; c) $\mathrm{MgH}_{2}$ obtained after three absorptions of hydrogen [11]. 


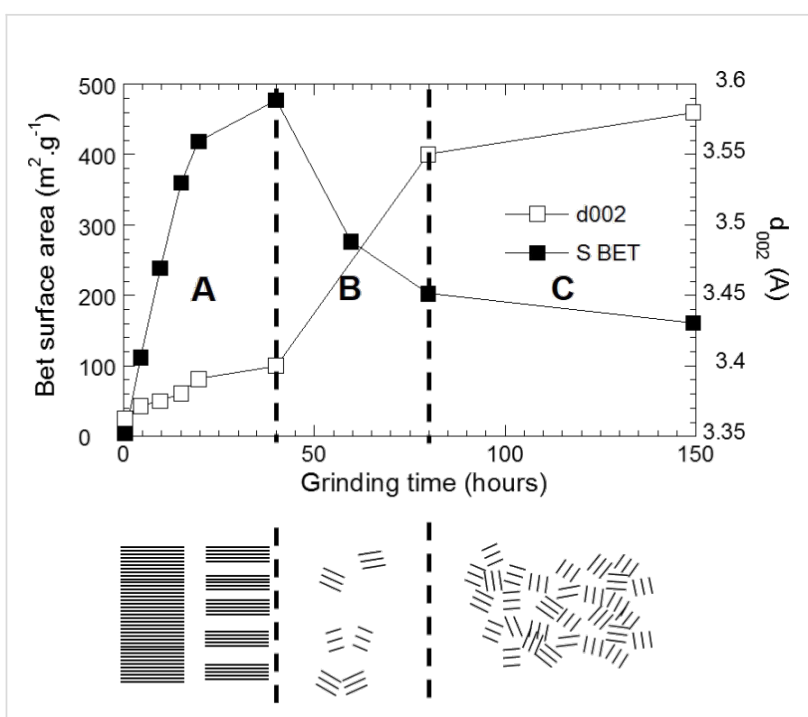

Figure 15: Graphite BET surface area $\left(\mathrm{m}^{2} \cdot \mathrm{g}^{-1}\right)$ and $d(002)$ interlayer distance $(\AA)$ as a function of grinding time $(h)$ [11].

$d(002)$ remains almost constant (step A) and then the BET surface area decrease and $d(002)$ drastically increases (step B). Firstly, The mechanical energy transferred to the carbon produces an exfoliation of the graphene layer. Then, the cumulated mechanical energy coming from the grinding is sufficient to promote fissure propagation within the graphene layer, resulting in the fracture of the $\mathrm{C}-\mathrm{C}$ covalent bonds, leading to the formation of very reactive edge carbon atoms and unstable particles which agglomerate together. The degree of disorder for carbonaceous materials increases with increased milling time and is proportional to the $d(002)$ distance, as previously established $[35,36]$. Note that the $\mathrm{C}$-free bonds created during the fracture of the graphene layer serve as oxygen scavengers, and their agglomeration and coating of the alloy particles enable a better chemical/physical protection against oxidation [34].

Based on the milling behavior of carbonaceous material [34,35], $\mathrm{MgH}_{2}$ is ground using a carbon having the maximum BET surface area in order to agglomerate carbon particles on $\mathrm{MgH}_{2}$ particles. DSC traces of $\mathrm{MgH}_{2}-10 \% \mathrm{C}_{t, z}$ composite obtained after $4 \mathrm{~h}$ of grinding shows a decrease of $48{ }^{\circ} \mathrm{C}$ of the desorption peak maximum of hydride carbon composite compared to the commercial hydride, as expected (Figure 16).

The dispersion of the hydride particles into carbon increases the thermal conductivity of the powder and helps the hydrogen release. With regard to the electrochemical properties, the potential-capacity curves of an electrode composite of $\mathrm{MgH}_{2}-10 \% \mathrm{C}_{t, z}$ obtained after $4 \mathrm{~h}$ of grinding shows a spectacular enhancement of the reversible capacity with $0.96 \mathrm{Li}$ $\left(=1000 \mathrm{~mA} \cdot \mathrm{h} \cdot \mathrm{g}^{-1}\right)$ for an irreversible loss of $48 \%$ (Figure $17 \mathrm{~b}$ ).

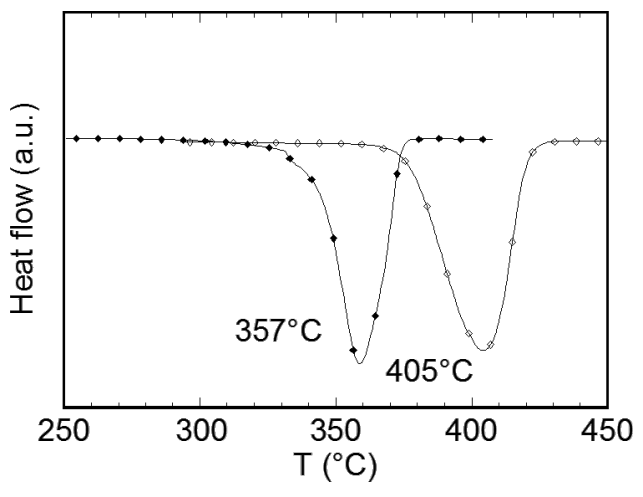

Figure 16: Thermodesorption of commercial $\mathrm{MgH}_{2}$ (black diamonds) and commercial $\mathrm{MgH}_{2}$ ground $4 \mathrm{~h}$ with $10 \%$ of $\mathrm{C}_{t, z}$ carbon (open diamonds) [11].

The grinding of $\mathrm{MgH}_{2}$ with carbon was also carried out with $\mathrm{MgH}_{2}$ that was activated through three sorption cycles. A synergic effect, involving both the hydride activation by solid-gas reaction and grinding with a $\mathrm{C}_{t, z}$ carbon to enhance the reversibility was noticed (Figure $17 \mathrm{c}, \mathrm{d}$ ). For instance, a capacity of $1500 \mathrm{~mA} \cdot \mathrm{h} \cdot \mathrm{g}^{-1}$ for an irreversible loss of $35 \%$ after three sorption cycles and $4 \mathrm{~h}$ of grinding with $10 \%$ of $\mathrm{C}_{t, z}$ carbon was obtained (Figure 17d). This reactivity enhancement enables to obtain interesting reversibilities, free of alloying reaction (with a cut of voltage of $0.15 \mathrm{~V} \mathrm{vs} \mathrm{Li}^{+} / \mathrm{Li}^{0}$ ). When the grinding time of the activated $\mathrm{MgH}_{2}+\mathrm{C}_{t, z}$ mixture varied from 4 to $6 \mathrm{~h}$, a reversible capacity of $1480 \mathrm{~mA} \cdot \mathrm{h} \cdot \mathrm{g}^{-1}$ for an irreversible loss of $25 \%$ is thus obtained at $0.15 \mathrm{~V} \mathrm{vs} \mathrm{Li}^{+} / \mathrm{Li}^{0}$ (Figure 18).

\section{III.5 Effect of reactive milling under hydrogen}

Reactive milling under hydrogen constitutes a powerful method for the synthesis of hydrides with the advantage to grind and to hydrogenate the sample in one single step. Applied to $\mathrm{MgH}_{2}$, a subsequent grinding step with carbon $\mathrm{C}_{t, z}$ is needed to obtain similar electrochemical performances than for the sample prepared by three hydrogen sorption steps followed by grinding with the carbon $\mathrm{C}_{t, z}\left(1600-1700 \mathrm{~mA} \cdot \mathrm{h} \cdot \mathrm{g}^{-1}\right.$ at $0.005 \mathrm{~V}$ vs $\mathrm{Li}^{+} / \mathrm{Li}^{0}$ for $6 \mathrm{~h}$ of grinding with carbon).

\section{III.6 Effect of metal catalyst addition to the $\mathrm{MgH}_{2}$ carbon composite}

The improvement of the sorption kinetics of $\mathrm{MgH}_{2}$ through catalyst addition (i.e., transition metals [37,38] transition metal oxides [39-41] and halides [42]) has been widely studied in the literature. $\mathrm{Nb}_{2} \mathrm{O}_{5}$ is one of the most efficient catalysts [43] enabling fast hydrogen desorption kinetics with $7.6 \mathrm{wt} \%$ of hydrogen desorbed in $100 \mathrm{~s}$ at $300{ }^{\circ} \mathrm{C}$. To improve the conversion reaction of $\mathrm{MgH}_{2}$ with lithium, the addition of a metal catalyst, which is more suitable than oxides in relation with the 

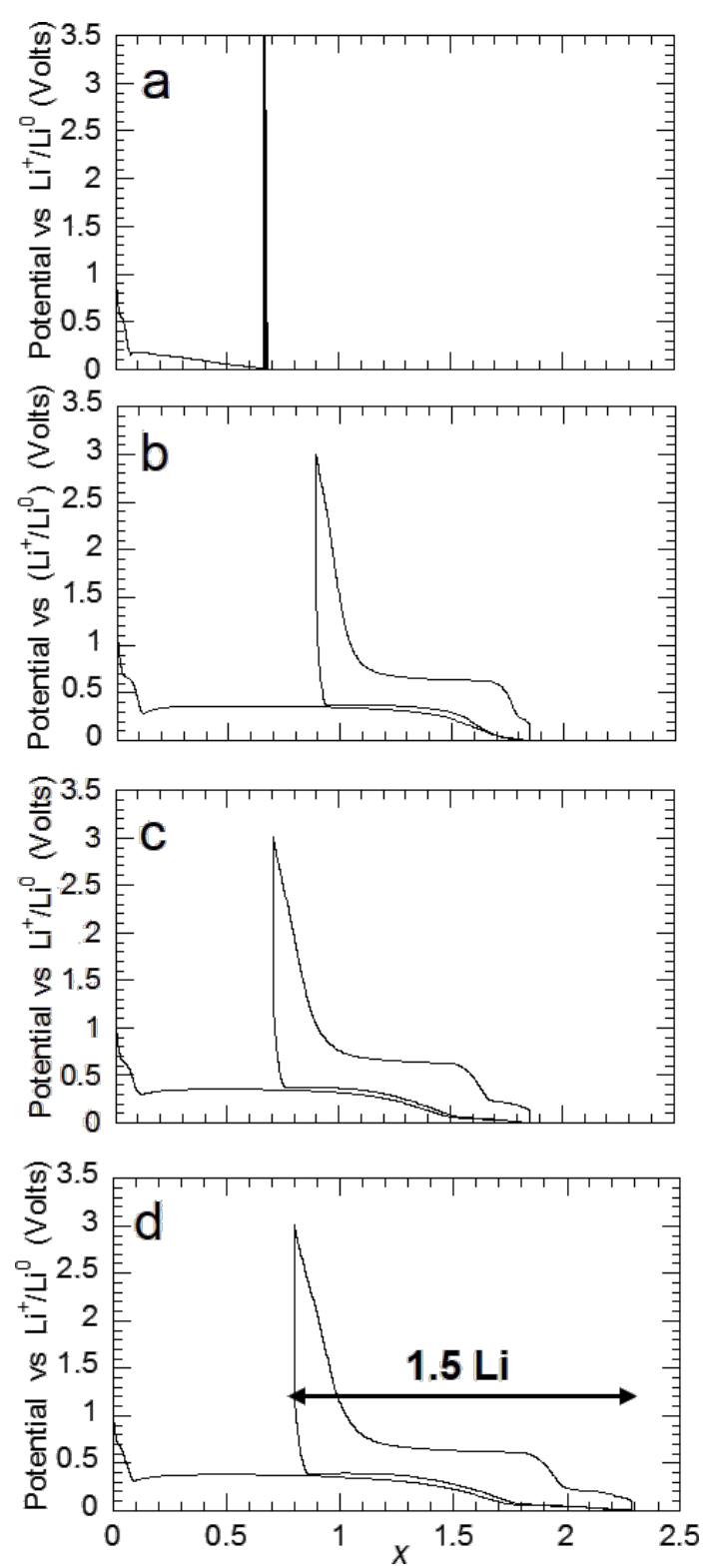

Figure 17: Evolution of the potential $(\mathrm{V})$ as a function of $x$ (mole fraction of $\mathrm{Li}$ ) for $\mathrm{MgH}_{2}$ electrodes cycled between 3 and $0.005 \mathrm{~V}$ at a rate of one equivalent of lithium in $10 \mathrm{~h}$. a) $\mathrm{MgH}_{2}$ commercial hydride; b) $\mathrm{MgH}_{2}$ commercial hydride ground for $4 \mathrm{~h}$ with $10 \%$ of $\mathrm{C}_{t, Z}$ carbon; c) $\mathrm{MgH}_{2}$ after one absorption of hydrogen and then ground for $4 \mathrm{~h}$ with $10 \%$ of $\mathrm{C}_{t, z}$ carbon; d) $\mathrm{MgH}_{2}$ after three absorptions of hydrogen and then ground for $4 \mathrm{~h}$ with $10 \%$ of $\mathrm{C}_{t, z}$ carbon [11].

electrode conductivity, has been reported by Nakayama et al. in a patent $[44,45]$. A charge-discharge efficiency of $93.9 \%$ for the conversion reaction with $\mathrm{MgH}_{2}$ is reported by the grinding addition of 3 atom \% of a nickel catalyst (particle size $20 \mathrm{~nm}$ ) in the hydride MCMB carbon mixture. In this last case the irreversible loss can be drastically reduced to $7 \%$ for a reversibility

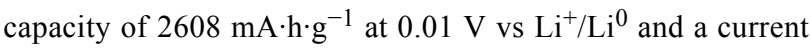
rate of $\mathrm{C} / 50$.
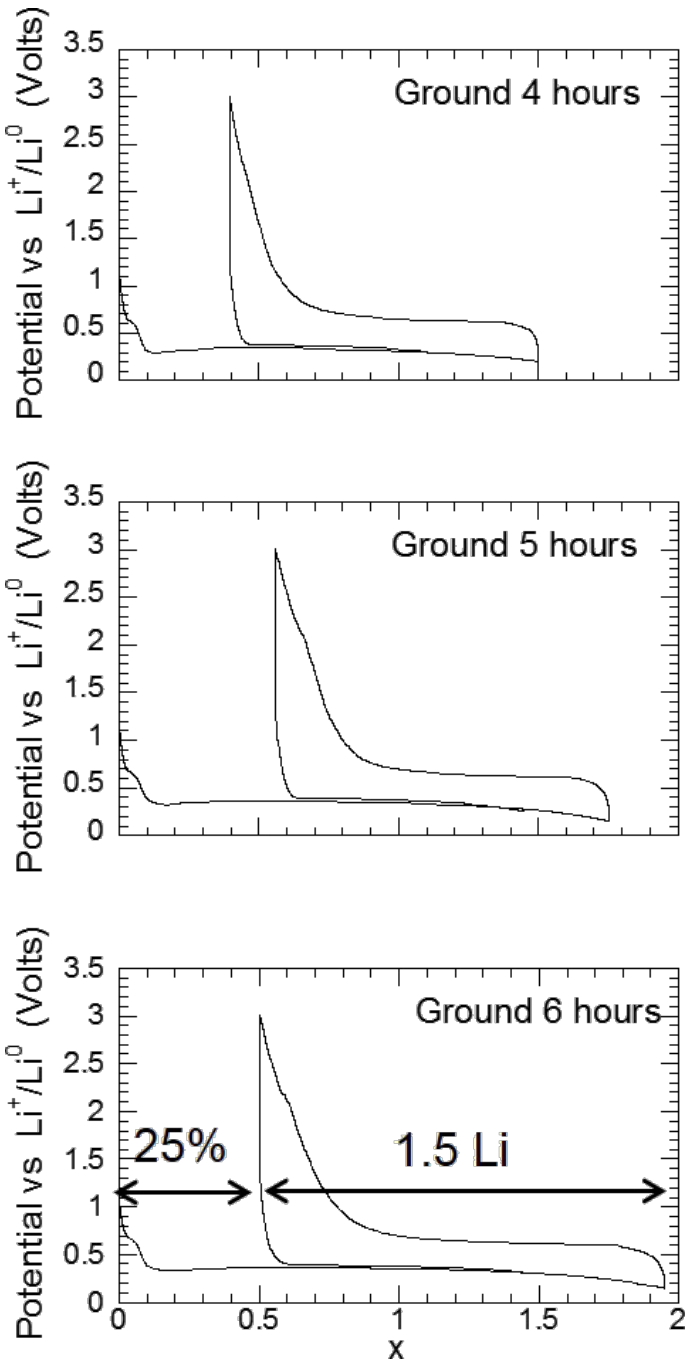

Figure 18: Evolution of the potential $(\mathrm{V})$ as a function of $x$ for a $\mathrm{Li} / \mathrm{MgH}_{2}$ cell that was cycled down to $0.15 \mathrm{~V}$ vs $\mathrm{Li}^{+} / \mathrm{Li}^{0}$ at a rate of one equivalent of lithium in $10 \mathrm{~h}$. $\left(\mathrm{MgH}_{2}\right.$ is obtained after three absorptions of hydrogen and then ground 4,5 or $6 \mathrm{~h}$ with $10 \%$ of $C_{t, z}$ carbon) [11].

\section{Performance improvements of hydride- based electrodes}

Different samples preparation methods for $\mathrm{MgH}_{2}-18 \% \mathrm{C}_{t, z}$ (activation by three hydrogen sorption steps or reactive milling followed by grinding with $\mathrm{C}_{t, z}$ carbon) are able to produce an hydride carbon composite electrode with full discharge capacity and $75 \%$ reversibility $\left(1500 \mathrm{~mA} \cdot \mathrm{h} \cdot \mathrm{g}^{-1}\right.$ at $\left.0.15 \mathrm{~V} \mathrm{vs} \mathrm{Li}^{+} / \mathrm{Li}^{0}\right)$ during the first charge for a current of one equivalent of electrons in $10 \mathrm{~h}$. Despite this improvement of the electrode reversibility of the $\mathrm{MgH}_{2}$ carbon composite, the cycle life is however limited due to the $83 \%$ volume variation, leading to an electronic interparticular conduction loss. Moreover, at a high current rate, the slow hydrogen motion leads to a limitation of the reversible capacity. The influence of the current rate and of the number of electrochemical cycles on the reactivity of the 
$\mathrm{MgH}_{2}$ carbon composite will be described in the two following paragraphs.

\section{IV.1 Influence of the current rate on the electrode reactivity: example of $\mathrm{MgH}_{2}$}

The experimental capacity decreases when the current rate increases and, for an exchange rate of one equivalent of electrons in one hour, the capacity is close to zero. This result shows that the reactivity improvement with different sample preparation methods is still insufficient for real application requiring electrode power and fast charge (Figure 19). However, for a thin film of $\mathrm{MgH}_{2}(200 \mathrm{~nm})$ (prepared by R. Griessen group at the Vrije Universiteit Amsterdam) a full discharge capacity of $2 \mathrm{Li}$ can be obtained for a current of one equivalent of electrons in one hour. This fact definitively confirms than the reduction of the diffusion distances is the key to achieve high power electrodes with hydrides for conversion reaction.

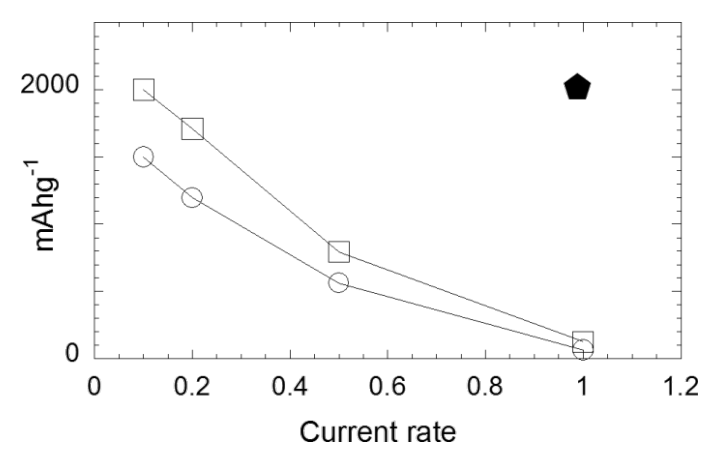

Figure 19: Capacities of a $\mathrm{MgH}_{2}$ electrode obtained after three absorptions of hydrogen and then ground for $4 \mathrm{~h}$ with $10 \%$ of $\mathrm{C}_{t, z}$ carbon as a function of the current rate (number of Li exchange per hours) open squares: discharge capacity, open circles: charge capacity; black pentagon: discharge capacity of a $\mathrm{MgH}_{2}$ thin film of $200 \mathrm{~nm}[11]$.

\section{IV.2 Effect of polymer binders on $\mathrm{MgH}_{2}$-based electrode cycle life}

The electrochemical cycling behavior of $\mathrm{MgH}_{2}-18 \% C_{t, z} / \mathrm{Li}$ was studied and compared with that of $\mathrm{MgH}_{2}-33.3 \%$ CMC-33.3\% $\mathrm{C}_{t, z} / \mathrm{Li}$ and $\mathrm{MgH}_{2}-33.3 \%$ CMC-f-33.3\% $\mathrm{C}_{t, z} / \mathrm{Li}$ cells where CMC and CMC-f are polymer binders (sodium carboxymethylcellulose and sodium carboxymethylcelluloseformate, respectively [46]). CMC [47,48], which was already widely investigated for silicon-based electrodes [49-60], surprisingly sustains the $270 \%$ volume change taking place during cycling of the Si-based electrode. Beattie et al. [54] estimated the CMC binder and carbon quantity needed to fill the holes created during lithium extraction from the Si alloy electrode to be around $66 \%$. It was experimentally confirmed that large capacities and long cycle lives of the electrodes are obtained for a $33 \% \mathrm{Si} / 33 \% \mathrm{CMC} / 33 \% \mathrm{C}$ mixture. This ratio of active material/binder/carbon was chosen to improve the electrode cycle life of $\mathrm{MgH}_{2}$. In addition to $\mathrm{CMC}$, a derivative binder with a formyl ester group was tested (CMC-f) [61].

$\mathrm{MgH}_{2}-18 \% \mathrm{C}_{t, z} / \mathrm{Li}, \mathrm{MgH}_{2}-33.3 \% \mathrm{CMC}-33.3 \% \mathrm{C}_{t, z} / \mathrm{Li}$ and $\mathrm{MgH}_{2}-33.3 \%$ CMC-f-33.3\% $\mathrm{C}_{t, z} /$ Li discharge-charge curves are shown in Figure 20. It appears there that high reversible capacities are preserved independently of the amount of active material additives in the electrode. Indeed, reversible capacities of $1700 \mathrm{~mA} \cdot \mathrm{h} \cdot \mathrm{g}^{-1}, 1800 \mathrm{~mA} \cdot \mathrm{h} \cdot \mathrm{g}^{-1}$ and $1900 \mathrm{~mA} \cdot \mathrm{h} \cdot \mathrm{g}^{-1}$ are obtained for the $\mathrm{MgH}_{2}-18 \% \mathrm{C}_{t, z} / \mathrm{Li}$ (Figure 20a), $\mathrm{MgH}_{2}-33.3 \%$ $\mathrm{CMC}-33.3 \% \mathrm{C}_{t, z} / \mathrm{Li}$ (Figure $20 \mathrm{~b}$ ) and $\mathrm{MgH}_{2}-33.3 \% \mathrm{CMC}-$ $\mathrm{f}-33.3 \% \mathrm{C}_{t, z} / \mathrm{Li}$ (Figure 20c) cells, respectively. An increase of the carbon content from 18 to $33 \%$ leads to an increase of the irreversible loss (from 25 to $39 \%$ ) due to electrolyte decomposition at the carbon surface. The reversible capacities of the $\mathrm{MgH}_{2}$ electrodes as a function of the cycle number are presented in Figure $21\left(\mathrm{MgH}_{2}-18 \% \mathrm{C}_{t, z} / \mathrm{Li}, \mathrm{MgH}_{2}-33.3 \%\right.$ $\mathrm{CMC}-33.3 \% \mathrm{C}_{t, z} / \mathrm{Li}$ and $\left.\mathrm{MgH}_{2}-33.3 \% \mathrm{CMC}-\mathrm{f}-33.3 \% \mathrm{C}_{t, z} / \mathrm{Li}\right)$. From theses curves it is clear that the presence of the CMC-type binder enhances the cycle life of the electrode. While a capacity value of $174 \mathrm{~mA} \cdot \mathrm{h} \cdot \mathrm{g}^{-1}$ is obtained for the electrode without binder, $240 \mathrm{~mA} \cdot \mathrm{h} \cdot \mathrm{g}^{-1}$ and $542 \mathrm{~mA} \cdot \mathrm{h} \cdot \mathrm{g}^{-1}$ are obtained for CMC and CMC-f binders after 40 cycles, respectively. The weak capacity, which originates from carbon $\left(20 \mathrm{mAh} \cdot \mathrm{g}^{-1}\right.$ after 40 cycles) is not at the origin of the better capacity retention of the $\mathrm{MgH}_{2}-33.3 \% \mathrm{CMC}-33.3 \% \mathrm{C}_{t, z} / \mathrm{Li}$ and $\mathrm{MgH}_{2}-33.3 \% \mathrm{CMC}-$ $\mathrm{f}-33.3 \% \mathrm{C}_{t, z} / \mathrm{Li}$ electrodes. Thus, porosity created by the polymers might explain the better volume accommodation of the electrode during lithium extraction. Further studies are needed for a better understanding of the nature of the polymeric interactions with carbon and metal hydride and their role during the solid mixing of CMC-type binders with $\mathrm{MgH}_{2}$ and $\mathrm{C}_{t, z}$.

\section{IV.3 Role of interface and particle size on reversibility of the conversion reaction: example of $\mathrm{TiH}_{2}$}

The reaction of titanium hydride $\left(\mathrm{TiH}_{2}\right)$ with lithium ions previously described involves a reaction path that can be summarized as follows:

$$
\begin{aligned}
& x \leq 0.34: \delta-\mathrm{TiH}_{2}(\mathrm{fcc})+0.34 \mathrm{Li} \rightarrow \delta-\mathrm{TiH}_{1.66}+0.34 \mathrm{LiH}, \\
& 0.34<x \leq 1: \delta-\mathrm{TiH}_{2-x}+x \mathrm{Li} \rightarrow \delta-\mathrm{TiH}(\mathrm{fco})+x \mathrm{LiH}, \\
& 1<x \leq 2: \delta-\mathrm{TiH}_{2-x}(\mathrm{fcc})+\delta-\mathrm{TiH}(\mathrm{fco})+\mathrm{Li} \rightarrow \alpha-\mathrm{Ti}(\mathrm{hcp})+\mathrm{LiH} .
\end{aligned}
$$

Within this conversion process, a full discharge capacity of $1072 \mathrm{~mA} \cdot \mathrm{h} \cdot \mathrm{g}^{-1}$ is obtained for the $\mathrm{TiH}_{2}$ ground with $10 \%$ of 

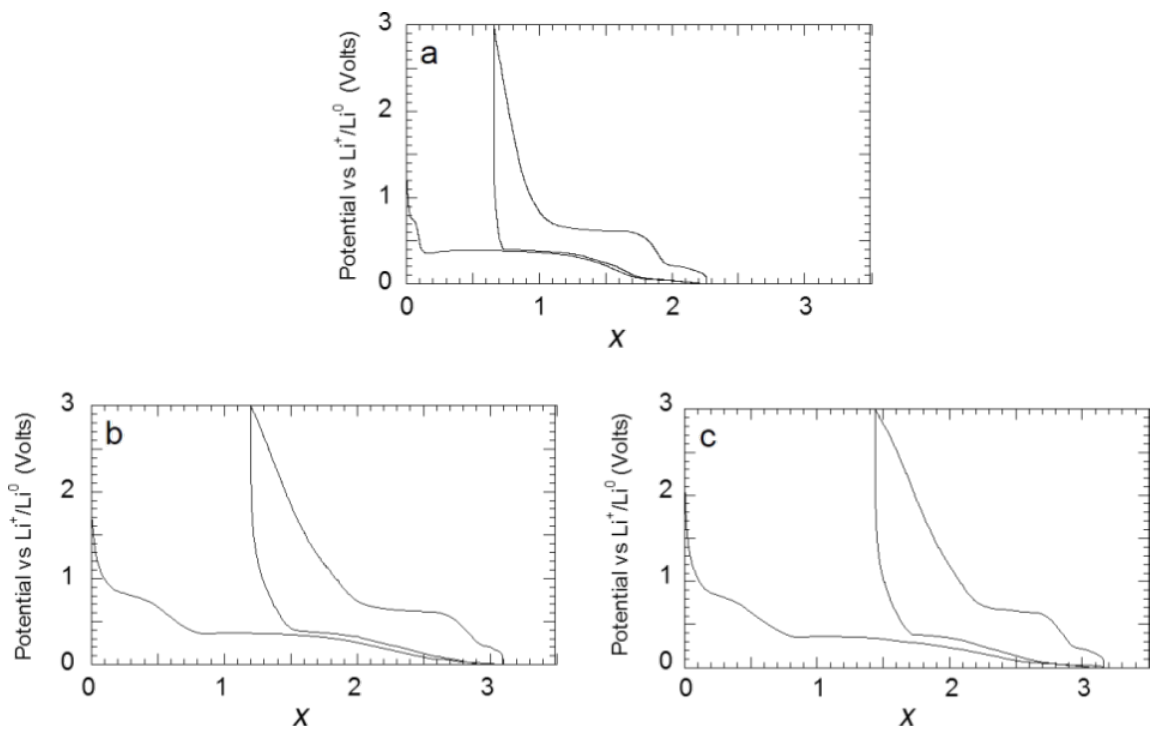

Figure 20: Evolution of the potential $(\mathrm{V})$ as a function of $x$ (mole fraction of $\mathrm{Li}$ ) for $\mathrm{MgH}_{2}$ electrodes cycled between 3 and $0.005 \mathrm{~V}$ at a rate of one equivalent of lithium in $10 \mathrm{~h}$. (a) $\mathrm{MgH}_{2}-18 \% \mathrm{C}_{t, z}$; (b) $33.3 \% \mathrm{MgH}_{2}-33.3 \% \mathrm{CMC}-33.3 \% \mathrm{C}_{t, z}$; (c) $33.3 \% \mathrm{MgH}_{2}-33.3 \% \mathrm{CMC}_{-}-33.3 \% \mathrm{C}_{t, z}$. Adapted from [46]. Copyright 2011 Elsevier.

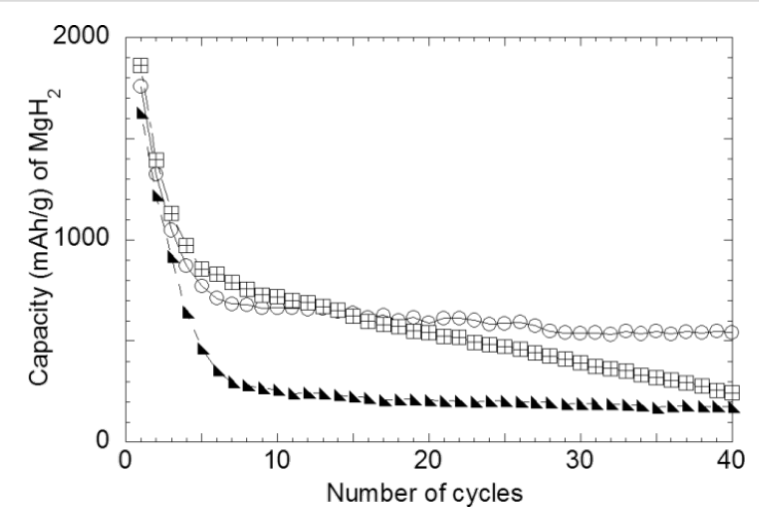

Figure 21: Electrochemical cycling performance for $\mathrm{MgH}_{2}$ composite electrodes: $\mathrm{MgH}_{2}-18 \% \mathrm{C}_{t, z}$ (black triangles), $33.3 \% \mathrm{MgH}_{2}-33.3 \%$ CMC-33.3\% $\mathrm{C}_{t, z}$ (open squares) and $33.3 \% \mathrm{MgH}_{2}-33.3 \% \mathrm{CMC}-$ $\mathrm{f}-33.3 \% \mathrm{C}_{t, z}$ (open circles). Cycling between 3 and $0.005 \mathrm{~V}$, rate of one equivalent of lithium in $10 \mathrm{~h}$. Adapted from [46]. Copyright 2011 Elsevier.
$\mathrm{C}_{t, z}$ carbon for $5 \mathrm{~h}$. However, while this reaction is free of any alloying reaction with lithium, no electrochemical reversibility was noticed during electrode charge (Figure 22a). To support the idea that interfaces and particles sizes play a key role on conversion reaction reversibility with titanium hydride, the electrochemical behavior of a $(2 \mathrm{LiH}+\mathrm{Ti})$ composite was studied [6]. This composite was prepared through a mechanochemical reaction between $\mathrm{TiH}_{2}$ and metallic Li. The capacity of the first charge reached $455 \mathrm{~mA} \cdot \mathrm{h} \cdot \mathrm{g}^{-1}$ whereas after one cycle the reversible capacity was still $428 \mathrm{~mA} \cdot \mathrm{h} \cdot \mathrm{g}^{-1}$, corresponding to a capacity retention of $94 \%$ (Figure $22 \mathrm{~b}$ ). The XRD pattern collected at the end of the first charge indicated the formation of titanium hydride in agreement with the theoretical conversion reaction: $2 \mathrm{LiH}+\mathrm{Ti} \rightarrow \mathrm{TiH}_{2}+2 \mathrm{Li}^{+}+2 \mathrm{e}^{-}$. This is a clear example showing that when thermodynamics allow a conversion reaction to occur, interfaces and particles size constitute the pertinent parameters that governs the process reversibility.
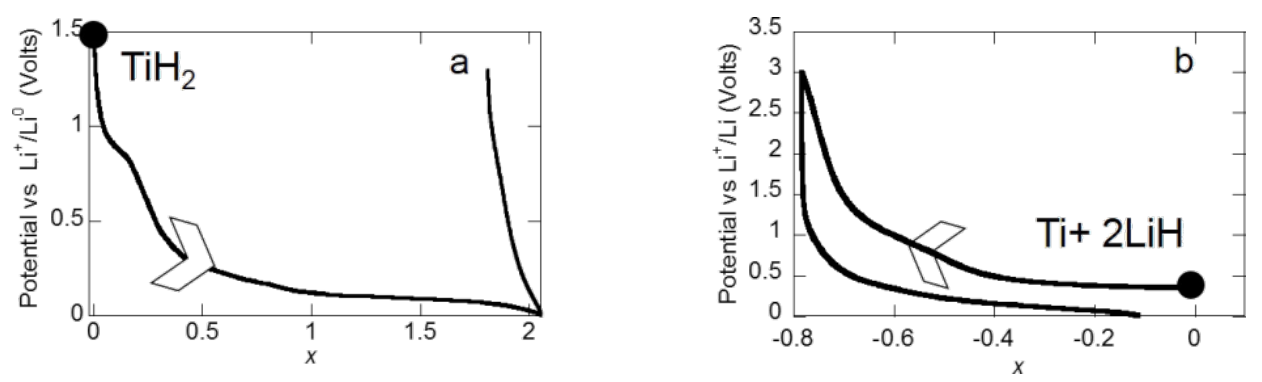

Figure 22: Potential profile of a) $\mathrm{TiH}_{2}$ electrode ground for $5 \mathrm{~h}$ with $10 \%$ of $\mathrm{C}_{t, z}$ carbon b) $\mathrm{Ti}+2 \mathrm{LiH}$ electrode as a function of $x$, the mole fraction of $\mathrm{Li}$ (rate one equivalent of $\mathrm{Li}$ in $100 \mathrm{~h}$ ). Adapted from [6]. Copyright 2009 Elsevier. 


\section{IV.4 Synthesis of nanoscale composite hydrides: a perspective to achieve all solid state batteries}

It must be emphasized first that production of hydride nanoparticles by reactive milling seems to be an unsuccessful route as long as the agglomeration of the freshly fractured particles is not controlled. Cryomilling could be a potential solution to avoid metal welding and to produce material on the laboratory scale, but this will require significant technological improvements to become economically viable for large scale material production.

Chemical methods, such as encapsulation or confinement strategies used in the design of energy storage and conversion materials, also constitute new synthetic routes that have shown promising results $[62,63]$. Thus, for solid-state hydrogen storage applications, very fast hydrogen absorption/desorption kinetics have been indeed confirmed for nanoscale $\mathrm{Mg}$ hydride $\left(\mathrm{MgH}_{2}\right)$ confined into the porosity of different carbon hosts $[64,65]$ or chemical matrices [66,67]. Very recently, composites containing $\mathrm{MgH}_{2}$ nanoparticles (with a narrow size distribution of 1-10 nm) which were well-dispersed into a porous carbon host have been prepared by Zlotea et al. [68]. These were produced with varying metal content up to $50 \mathrm{wt} \%$ and were designed to be used as a negative electrode for Li-ion batteries. These composites show interesting electrochemical behavior, especially regarding their cycle life stability $\left(500 \mathrm{~mA} \cdot \mathrm{h} \cdot \mathrm{g}^{-1}\right.$ after 40 cycles) and have a stable nanoparticle size distribution during electrochemical cycling.

Other promising materials, produced through a physical vapor transport deposition method such as $\mathrm{Mg} / \mathrm{MgH}_{2}$ nanowires or nanofibers are under development for a few years now [69-71]. For instance $\mathrm{Mg}$ nanowire shows interesting modifications of both thermodynamics and kinetics compared to the bulk material: a decrease of the dissociation energy of about $12 \%$, (30-50 nm nanowires: $65.3 \mathrm{~kJ} \cdot\left(\mathrm{mol} \mathrm{H}_{2}\right)^{-1}$ bulk material: $\left.74 \mathrm{~kJ} \cdot\left(\mathrm{mol} \mathrm{H}_{2}\right)^{-1}\right)$.

Hydriding chemical vapor deposition (HCVD) is also a powerful method to produce in situ high purity nano/microscale $\mathrm{MgH}_{2}$ under hydrogen. This method, which enables to play with temperature and pressure, is a nice tool for the preparation of a variety of particles having controlled size and shapes (nanofibers, nanoparticles, microdendrites, irregular bulk, hexagonal microplates and microspheres). A good picture of this synthesis method, leading to the production of tailored materials, is given by a pressure-temperature diagram, similar to the diagram of Nakaya et al. [72]. Mass production and applications of such materials in the field of hydrogen storage and batteries technologies will be an interesting challenge for the next decade.

\section{IV.5 Use of computational methods to look for better materials}

Computational methods can also offer interesting alternatives to help the search and development of materials for hydrogen storage and batteries. The idea is, for instance, to look for materials having high volume capacity, minimal expansion volume and high lithium mobility. A recent study by molecular dynamics simulations has revealed that the Li diffusion in $\mathrm{MgH}_{2}$ nanocluster doped with $\mathrm{Fe}, \mathrm{Ni}$, Ti or $\mathrm{V}$ is independent of the presence of the transitions metal [73]. The metals improve the hydrogen desorption kinetics. Again, this example shows the mutual interest of this kind of device for hydrogen storage and batteries technologies.

The search for the existence of new stable hydrides in the $\mathrm{Mg}-\mathrm{Li}-\mathrm{H}$ system was also addressed by several groups through density functional theory approach (DFT) [74,75]. Ternary hydrides in the system $\mathrm{Li}-\mathrm{Mg}-\mathrm{H}$, such as $\mathrm{Li}_{2} \mathrm{MgH}_{4}$ and $\mathrm{LiMgH}_{3}$, are insulators dominated by ionic bonds. Their preparation from $\mathrm{Li}, \mathrm{Mg}$ and $\mathrm{H}_{2}$ is energetically favorable, but may be kinetically inhibited by separation into pure phases. The effects of various light-metal (Mg, Al, Li) and transition-metals (V, Cr, $\mathrm{Mn}, \mathrm{Fe}, \mathrm{Co}, \mathrm{Cu}, \mathrm{Zn}$ ) dopant on the electrochemical properties of $\mathrm{NiTiH}$ hydrides as anodes for Li-ion batteries where theoretically studied by Qian et al. [76,77] with Al, Cr, Mn and Fe being the most promising according to the authors.

\section{Conclusion}

Studies of the reaction of hydrides with lithium ions started with the pioneer work with $\mathrm{MgH}_{2}$, where lithium-driven conversion reactions were firstly demonstrated for the metal hydride family. The study was subsequently extended to other metal and complex hydrides, especially $\mathrm{TiH}_{2}$ and $\mathrm{AlH}_{3}$, and is in now in progress, particularly because of the important number of different potential interesting compounds [78]. Metal hydrides present the advantage of having high capacities in a safe potential window of $0.1-1 \mathrm{~V}$ vs $\mathrm{Li}^{+} / \mathrm{Li}^{0}$. Moreover, these hydrides show the lowest polarization reported to date for conversion reaction electrodes, as compared to oxides, sulfides, nitrides, phosphides and fluorides compounds, and therefore, constitute promising candidates for negative electrodes in $\mathrm{Li}$-ion batteries.

This research field focuses now mainly on nanocomposite synthesis in order to enhance the limited electrochemical cycling performances, the main drawback of hydrides. Electrode technology is, thus, the next challenge, considering the design of the current collector, the preparation of polymeric binders and the mixing of hydride and electrolyte together with careful studies to achieve better capacity retention performance or to scale up the nanocomposite elaboration process. On the other hand, the results obtained at the present time emphasize the importance of 
the knowledge of fundamentals aspects to control the conversion complex process where reaction paths, interfaces and particle size are the keys parameters. Use of hydrides as anode for Li-ion batteries needs also strong interactions between batteries and fuel-cell communities to be wholly fruitful [79]. In the final analysis, hydrides as a new concept for negative electrodes bridges Li-ion battery and hydrogen storage technologies together and can constitute a promising opportunity for the discovery and the achievement of new energy storage technology for the next 20 years.

\section{References}

1. Cabana, J.; Monconduit, L.; Larcher, D.; Palacín, M. R. Adv. Mater. 2010, 22, E170-E192. doi:10.1002/adma.201000717

2. Bruce, P. G.; Scrosati, B.; Tarascon, J.-M. Angew. Chem., Int. Ed. 2008, 47, 2930-2946. doi:10.1002/anie.200702505

3. Breitung, B.; Reddy, M. A.; Chakravadhanula, V. S. K.; Engel, M.; Kübel, C.; Powell, A. K.; Hahn, H.; Fichtner, M. Beilstein J. Nanotechnol. 2013, 4, 705-713. doi:10.3762/bjnano.4.80

4. Nitta, N.; Yushin, G. Part. Part. Syst. Charact. 2014, 31, 317-336. doi:10.1002/ppsc.201300231

5. Oumellal, Y.; Rougier, A.; Nazri, G. A.; Tarascon, J.-M.; Aymard, L. Nat. Mater. 2008, 7, 916-921. doi:10.1038/nmat2288

6. Oumellal, Y.; Rougier, A.; Tarascon, J.-M.; Aymard, L. J. Power Sources 2009, 192, 698-702. doi:10.1016/j.jpowsour.2009.03.003

7. HSC Chemistry, v5.11; Chemistry Software Ltd.: South Nutfield, Surrey, UK.

8. Griessen, R.; Riesterer, T. Hydrogen in intermetallic compounds I. In Hydrogen in intermetallic compounds I; Schlapbach, L., Ed.; Topics in Applied Physics, Vol. 63; Springer, 1988; pp 219-284. doi:10.1007/3540183337_13

9. Sandrock, G. D.; Huston, E. L. CHEMTECH 1981, 11, 754-762.

10. Oumellal, Y.; Zaïdi, W.; Bonnet, J.-P.; Cuevas, F.; Latroche, M.; Zhang, J.; Bobet, J.-L.; Rougier, A.; Aymard, L. Int. J. Hydrogen Energy 2012, 37, 7831-7835. doi:10.1016/j.ijhydene.2012.01.107

11. Oumellal, Y. Réactivité électrochimique des hydrures métalliques vis-à-vis du lithium. Ph.D. Thesis, Université de Picardie, Jules Verne, France, 2009.

12. Bououdina, M.; Oumellal, Y.; Dupont, L.; Aymard, L.; Al-Gharni, H.; Al-Hajry, A.; Maark, T. A.; De Sarkar, A.; Ahuja, R.; Deshpande, M. D.; Qian, Z.; Rahane, A. B. Mater. Chem. Phys. 2013, 141, 348-354. doi:10.1016/j.matchemphys.2013.05.021

13. Zaïdi, W.; Bonnet, J.-P.; Zhang, J.; Cuevas, F.; Latroche, M.; Couillaud, S.; Bobet, J.-L.; Sougrati, M. T.; Jumas, J.-C.; Aymard, L. Int. J. Hydrogen Energy 2013, 38, 4798-4808. doi:10.1016/j.ijhydene.2013.01.157

14.Zhang, J.; Cuevas, F.; Zaïdi, W.; Bonnet, J.-P.; Aymard, L.; Bobet, J.-L.; Latroche, M. J. Phys. Chem. C 2011, 115, 4971-4979. doi:10.1021/jp2005293

15. Hanada, N.; Kamura, A.; Suzuki, H.; Takai, K.; Ichikawa, T.; Kojima, Y. J. Alloys Compd. 2011, 509, S584-S587. doi:10.1016/j.jallcom.2010.10.069

16. Fleischmann, S.; Bekaert, E.; Emmel, U.; Wohlfahrt-Mehrens, M., Eds. Trilithium hexahydroaluminate $\left(\mathrm{Li}_{3} \mathrm{Al} \mathrm{H}_{6}\right)$ as negative electrode material for lithium-ion batteries, 2nd International Conference on Materials for Energy, Karlsruhe, Germany, May 12-16, 2013; EnMat II: Karlsruhe, Germany, 2013
17. Latroche, M.; Cuevas, F.; Zhang, J., Eds. Nanostuctured Metal Hydrides as Efficient Anode Materials for Advanced Batteries, TMS 2014, 143rd annual meeting, San Diego, California, USA, Feb 16-20, 2014; San Diego, California, USA, 2014.

18. Teprovich, J. A., Jr.; Zhang, J.; Colón-Mercado, H.; Cuevas, F.; Peters, B.; Greenway, S.; Zidan, R.; Latroche, M. J. Phys. Chem. C 2015, 119, 4666-4674. doi:10.1021/jp5129595

19. Zaidi, W. Hydrures: matériaux de conversion pour accumulateurs lithium-ion. Ph.D. Thesis, Université de Picardie, Jules Verne, France, 2013.

20. Bobet, J.-L.; Pechev, S.; Chevalier, B.; Darriet, B. J. Mater. Chem. 1999, 9, 315-318. doi:10.1039/a804971h

21. Nayeb-Hashemi, A.; Clark, J. J. Phase Equilib. 1985, 6, 238-244.

22. Zhang, J.; Zaïdi, W.; Paul-Boncour, V.; Provost, K.; Michalowicz, A.; Cuevas, F.; Latroche, M.; Belin, S.; Bonnet, J.-P.; Aymard, L. J. Mater. Chem. A 2013, 1, 4706-4717. doi:10.1039/c3ta01482g

23. Selvam, P.; Viswanathan, B.; Swamy, C. S.; Srinivasan, V. Int. J. Hydrogen Energy 1988, 13, 749-759. doi:10.1016/0360-3199(88)90036-5

24. Selvam, P.; Viswanathan, B.; Swamy, C. S.; Srinivasan, V. Thermochim. Acta 1988, 125, 1-8. doi:10.1016/0040-6031(88)87205-8

25. Mg hydride based system conversion reaction with lithium ion Unpublished work.

26. Couillaud, S.; Kirikova, M.; Zaïdi, W.; Bonnet, J.-P.; Marre, S.; Aymonier, C.; Zhang, J.; Cuevas, F.; Latroche, M.; Aymard, L.; Bobet, J.-L. J. Alloys Compd. 2013, 574, 6-12. doi:10.1016/j.jallcom.2013.03.229

27. Braga, M. H.; El-Azab, A. Phys. Chem. Chem. Phys. 2014, 16, 23012-23025. doi:10.1039/C4CP01815J

28. Latroche, M.; Kalisvaart, P.; Notten, P. H. L. J. Solid State Chem. 2006, 179, 3024-3032. doi:10.1016/j.jssc.2006.05.032

29. Libowitz, G. G. The Solid State Chemistry of Binary Metal Hydrides; W.A. Benjamin: New York, 1965.

30. Sandia National Laboratories, Hydride Information Center. http://www.sandia.gov/ (accessed Oct 8, 2014).

31. Moysés Araùjo, C.; Ahuja, R. J. Alloys Compd. 2005, 404-406, 220-223. doi:10.1016/j.jallcom.2004.10.085

32. Gremaud, R.; Broedersz, C. P.; Borsa, D. M.; Borgschulte, A.; Mauron, P.; Schreuders, H.; Rector, J. H.; Dam, B.; Griessen, R. Adv. Mater. 2007, 19, 2813-2817. doi:10.1002/adma.200602560

33. Vermeulen, P.; Niessen, R. A. H.; Notten, P. H. L. Electrochem. Commun. 2006, 8, 27-32. doi:10.1016/j.elecom.2005.10.013

34. Aymard, L.; Lenain, C.; Courvoisier, L.; Salver-Disma, F.; Tarascon, J.-M. J. Electrochem. Soc. 1999, 146, 2015-2023. doi:10.1149/1.1391884

35. Disma, F.; Aymard, L.; Dupont, L.; Tarascon, J.-M. J. Electrochem. Soc. 1996, 143, 3959-3972. doi:10.1149/1.1837322

36. Dahn, J. R.; Sleigh, A. K.; Shi, H.; Reimers, J. N.; Zhong, Q.; Way, B. M. Electrochim. Acta 1993, 38, 1179-1191. doi:10.1016/0013-4686(93)80048-5

37. Liang, G.; Huot, J.; Boily, S.; Schulz, R. J. Alloys Compd. 2000, 305, 239-245. doi:10.1016/S0925-8388(00)00708-8

38. Liang, G.; Huot, J.; Boily, S.; Van Neste, A.; Schulz, R. J. Alloys Compd. 1999, 292, 247-252. doi:10.1016/S0925-8388(99)00442-9

39. Barkhordarian, G.; Klassen, T.; Bormann, R. J. Alloys Compd. 2004, 364, 242-246. doi:10.1016/S0925-8388(03)00530-9

40. Barkhordarian, G.; Klassen, T.; Bormann, R. Scr. Mater. 2003, 49, 213-217. doi:10.1016/S1359-6462(03)00259-8 
41. Ikeda, S.; Ichikawa, T.; Yamaguchi, S.; Miyaoka, H.; Kojima, Y. J. Jpn. Inst. Energy 2014, 93, 926-930. doi:10.3775/jie.93.926

42. Bhat, V. V.; Rougier, A.; Aymard, L.; Darok, X.; Nazri, G.; Tarascon, J. M. J. Power Sources 2006, 159, 107-110. doi:10.1016/j.jpowsour.2006.04.059

43. Borgschulte, A.; Lohstroh, W.; Westerwaal, R. J.; Schreuders, H.; Rector, J. H.; Dam, B.; Griessen, R. J. Alloys Compd. 2005, 404-406, 699-705. doi:10.1016/j.jallcom.2005.01.137

44. Nakayama, H.; Matsunaga, T.; Nobuhara, K.; Kon, M. Anode material, metal secondary battery, and method for production of anode material. U.S. Patent Appl. WO 2012/007830 A1, Jan 19, 2012.

45. Nakayama, H.; Nobuhara, K.; Kon, M.; Matsunaga, T. 218th ECS Meeting Abstract 2010, 1002, 1052.

46. Zaïdi, W.; Oumellal, Y.; Bonnet, J.-P.; Zhang, J.; Cuevas, F.; Latroche, M.; Bobet, J.-L.; Aymard, L. J. Power Sources 2011, 196, 2854-2857. doi:10.1016/j.jpowsour.2010.11.048

47. Heinze, T.; Koschella, A. Macromol. Symp. 2005, 223, 13-40. doi:10.1002/masy.200550502

48. Heinze, T. Macromol. Chem. Phys. 1998, 199, 2341-2364. doi:10.1002/(SICI)1521-3935(19981101)199:11<2341::AID-MACP2341 $>3.0 . \mathrm{CO} ; 2-\mathrm{J}$

49. Urbonaite, S.; Baglien, I.; Ensling, D.; Edström, K. J. Power Sources 2010, 195, 5370-5373. doi:10.1016/j.jpowsour.2010.03.042

50. Guo, J.; Wang, C. Chem. Commun. 2010, 46, 1428-1430. doi:10.1039/b918727h

51. Mazouzi, D.; Lestriez, B.; Roué, L.; Guyomard, D. Electrochem. Solid-State Lett. 2009, 12, A215-A218. doi:10.1149/1.3212894

52. Bridel, J.-S.; Azaïs, T.; Morcrette, M.; Tarascon, J.-M.; Larcher, D. Chem. Mater. 2010, 22, 1229-1241. doi:10.1021/cm902688w

53. Hochgatterer, N. S.; Schweiger, M. R.; Koller, S.; Raimann, P. R.; Wöhrle, T.; Wurm, C.; Winter, M. Electrochem. Solid-State Lett. 2008, 11, A76-A80. doi:10.1149/1.2888173

54. Beattie, S. D.; Larcher, D.; Morcrette, M.; Simon, B.; Tarascon, J.-M. J. Electrochem. Soc. 2008, 155, A158-A163. doi:10.1149/1.2817828

55. Li, J.; Lewis, R. B.; Dahn, J. R. Electrochem. Solid-State Lett. 2007, 10, A17-A20. doi:10.1149/1.2398725

56. Lestriez, B.; Bahri, S.; Sandu, I.; Roué, L.; Guyomard, D. Electrochem. Commun. 2007, 9, 2801-2806. doi:10.1016/j.elecom.2007.10.001

57. Dimov, N.; Xia, Y.; Yoshio, M. J. Power Sources 2007, 171, 886-893. doi:10.1016/j.jpowsour.2007.06.026

58. Yoshio, M.; Tsumura, T.; Dimov, N. J. Power Sources 2006, 163, 215-218. doi:10.1016/j.jpowsour.2005.12.078

59. Buqa, H.; Holzapfel, M.; Krumeich, F.; Veit, C.; Novák, P. J. Power Sources 2006, 161, 617-622. doi:10.1016/j.jpowsour.2006.03.073

60. Liu, W.-R.; Yang, M.-H.; Wu, H.-C.; Chiao, S. M.; Wu, N.-L. Electrochem. Solid-State Lett. 2005, 8, A100-A103. doi:10.1149/1.1847685

61. Heinze, T.; Heinze, U. Macromol. Rapid Commun. 1997, 18, 1033-1040. doi:10.1002/marc.1997.030181206

62. Schüth, F. Chem. Mater. 2014, 26, 423-434. doi:10.1021/cm402791v

63. Zlotea, C.; Latroche, M. Colloids Surf., A 2013, 439, 117-130. doi:10.1016/j.colsurfa.2012.11.043

64. Zlotea, C.; Chevalier-César, C.; Léonel, E.; Leroy, E.; Cuevas, F.; Dibandjo, P.; Vix-Guterl, C.; Martens, T.; Latroche, M. Faraday Discuss. 2011, 151, 117-131. doi:10.1039/c0fd00016g

65. Nielsen, T. K.; Manickam, K.; Hirscher, M.; Besenbacher, F.; Jensen, T. R. ACS Nano 2009, 3, 3521-3528. doi:10.1021/nn901072w
66. Zhao-Karger, Z.; Hu, J.; Roth, A.; Wang, D.; Kübel, C.; Lohstroh, W.; Fichtner, M. Chem. Commun. 2010, 46, 8353-8355. doi:10.1039/c0cc03072d

67. Paskevicius, M.; Sheppard, D. A.; Buckley, C. E. J. Am. Chem. Soc. 2010, 132, 5077-5083. doi:10.1021/ja908398u

68. Oumellal, Y.; Zlotea, C.; Bastide, S.; Cachet-Vivier, C.; Léonel, E.; Sengmany, S.; Leroy, E.; Aymard, L.; Bonnet, J.-P.; Latroche, M. Nanoscale 2014, 6, 14459-14466. doi:10.1039/C4NR03444A

69. Zhu, C.; Hosokai, S.; Matsumoto, I.; Akiyama, T. Cryst. Growth Des. 2010, 10, 5123-5128. doi:10.1021/cg100856n

70. Matsumoto, I.; Akiyama, T.; Nakamura, Y.; Akiba, E. J. Alloys Compd. 2010, 507, 502-507. doi:10.1016/j.jallcom.2010.07.218

71. Zhu, C.; Hayashi, H.; Saita, I.; Akiyama, T. Int. J. Hydrogen Energy 2009, 34, 7283-7290. doi:10.1016/j.jijydene.2009.06.080

72. Nakaya, U. Snow Crystals, Natural and Artificial; Harvard University Press: Cambridge, MA, USA, 1954. doi:10.4159/harvard.9780674182769

73. Ramzan, M.; Lebègue, S.; Ahuja, R. Int. J. Hydrogen Energy 2010, 35, 10373-10376. doi:10.1016/j.ijhydene.2010.07.024

74. Mason, T. H.; Liu, X.; Hong, J.; Graetz, J.; Majzoub, E. H. J. Phys. Chem. C 2011, 115, 16681-16687. doi:10.1021/jp203056n

75. Li, D.; Zhang, T.; Yang, S.; Tao, Z.; Chen, J. J. Alloys Compd. 2011, 509, 8228-8234. doi:10.1016/j.jallcom.2011.05.084

76. Qian, Z.; Jiang, X.; De Sarkar, A.; Adit Maark, T.; Deshpande, M. D.; Bououdina, M.; Johansson, B.; Ahuja, R. Solid State lonics 2014, 258, 88-91. doi:10.1016/j.ssi.2014.02.007

77. Qian, Z.; De Sarkar, A.; Adit Maark, T.; Jiang, X.; Deshpande, M. D.; Bououdina, M.; Ahuja, R. Appl. Phys. Lett. 2013, 103, 033902. doi:10.1063/1.4813596

78. Wietelmann, U. Chem. Ing. Tech. 2014, 86, 2190-2194. doi:10.1002/cite.201400097

79. Fichtner, M. J. Alloys Compd. 2011, 509 (Suppl. 2), S529-S534. doi:10.1016/j.jallcom.2010.12.179

\section{License and Terms}

This is an Open Access article under the terms of the Creative Commons Attribution License (http://creativecommons.org/licenses/by/2.0), which permits unrestricted use, distribution, and reproduction in any medium, provided the original work is properly cited.

The license is subject to the Beilstein Journal of Nanotechnology terms and conditions: (http://www.beilstein-journals.org/bjnano)

The definitive version of this article is the electronic one which can be found at: doi:10.3762/bjnano.6.186 